\title{
Anti-inflammatory and anti-invasive effects of $\alpha$-melanocyte- stimulating hormone in human melanoma cells
}

\author{
P Eves', J Haycock ${ }^{2}$, C Layton ${ }^{3}$, M Wagner', H Kemp', M Szabo², R Morandini ${ }^{4}$, G Ghanem ${ }^{4}$, JC García-Borrón ${ }^{5}$, \\ C Jiménez-Cervantes ${ }^{5}$ and $S$ Mac Neil ${ }^{*, 1,2}$ \\ 'University Section of Medicine, Division of Clinical Sciences, Northern General Hospital, Sheffield S5 7AU, UK; ' ${ }^{2}$ Department of Engineering Materials, \\ University of Sheffield, Mappin Street, Sheffield SI 3JD, UK; ${ }^{3}$ Department of Histopathology, Northern General Hospital Trust, Sheffield S5 7AU, UK: \\ ${ }^{4}$ Laboratory of Oncology and Experimental Surgery, Institut Bordet, Université Libre de Bruxelles, Belgium; ${ }^{5}$ Department of Biochemistry and Molecular \\ Biology, School of Medicine, University of Murcia, Apto 4021, 30100 Espinardo, Murcia, Spain
}

$\alpha$-Melanocyte stimulating hormone $(\alpha-M S H)$ is known to have pleiotrophic functions including pigmentary, anti-inflammatory, antipyretic and immunoregulatory roles in the mammalian body. It is also reported to influence melanoma invasion with levels of $\alpha$-, $\beta$ - and $\gamma$-MSH correlated clinically with malignant melanoma development, but other studies suggest $\alpha$-MSH acts to retard invasion. In the present study, we investigated the action of $\alpha-\mathrm{MSH}$ on three human melanoma cell lines (HBL, A375-SM and C8I6I) differing in metastatic potential. $\alpha$-melanocyte-simulating hormone reduced invasion through fibronectin and also through a human reconstructed skin composite model for the HBL line, and inhibited proinflammatory cytokine-stimulated activation of the NF- $\kappa \mathrm{B}$ transcription factor. However, A375-SM and C816I cells did not respond to $\alpha$-MSH. Immunofluorescent microscopy and Western blotting identified melanocortin-I receptor (MC-IR) expression for all three lines and MC-2R on HBL and A375-SM lines. Receptor binding identified a similar affinity for $\alpha-\mathrm{MSH}$ for all three lines with the highest number of binding sites on HBL cells. Only the HBL melanoma line demonstrated a detectable cyclic adenosine monophosphate (cAMP) response to $\alpha$-MSH, although all three lines responded to acute $\alpha$-MSH addition ( + (-)- $N^{6}$-(2-phenylisopropyl)-adenosine (PIA)) with an elevation in intracellular calcium. The nonresponsive lines displayed MC-IR polymorphisms (C8I6I, Arg (wt) I5I/Cys I5I; A375-SM, homozygous Cys I5I), whereas the HBL line was wild type. Stable transfection of the C8I6I line with wild-type MC-IR produced cells whose invasion was significantly inhibited by $\alpha-M S H$. From this data, we conclude that $\alpha-M S H$ can reduce melanoma cell invasion and protect cells against proinflammatory cytokine attack in cells with the wild-type receptor $(\mathrm{HBL})$.

British Journal of Cancer (2003) 89, 2004-20 I5. doi:I0.I038/sj.bjc.660 I 349 www.bjcancer.com

(c) 2003 Cancer Research UK

Keywords: melanoma; $\alpha-M S H$; melanocortin; NF-kappaB; metastasis

The aim of this study was to investigate how $\alpha$-melanocytesimulating hormone $(\alpha-\mathrm{MSH})$ affects melanoma cell invasion and resistance to proinflammatory cytokines. $\alpha$-melanocyte-simulating hormone arises from the proteolytic cleavage of pro-opiomelanocortin (POMC) and is responsible for pigmentation in lower vertebrates (Eberle 1988). POMC and $\alpha-\mathrm{MSH}$ are synthesised by normal human keratinocytes and melanocytes (Schauer et al, 1994; Kippenberger et al, 1995; Chakraborty et al, 1996), and administration in vivo can produce skin darkening in humans (Lerner and McGuire 1961). Although cultured mouse melanocytes and melanoma cells reliably pigment to $\alpha$-MSH addition (Eberle, 1988), human melanocytes have little or no response (Friedmann et al, 1990; De Luca et al, 1993; Hedley et al, 1998a). Responses relate to skin type (Hunt et al, 1994) with melanocytes from type 1 and type 2 skin donors rarely pigmenting to $\alpha$-MSH in vitro,

* Correspondence: Professor S Mac Neil, University Section of Medicine, Division of Clinical Sciences (North), Northern General Hospital, Sheffield S5 7AU; UK; E-mail: s.macneil@shef.ac.uk

Received 20 May 2003; revised 3 September 2003; accepted 3 September 2003 whether in 2-D (Hedley et al, 1998a) or 3-D culture (Hedley et al, 2002).

$\alpha$-Melanocyte-simulating hormone also has potent antipyretic and anti-inflammatory responses, inhibiting acute and chronic inflammation in a number of tissues (Lipton and Catania, 1997), including for example ultraviolet (UV) irradiation (Luger et al, 1999). Our group has showed that $\alpha$-MSH can inhibit tumour necrosis factor- $\alpha$ (TNF- $\alpha$ )-induced upregulation of intercellular adhesion molecule-1 (ICAM-1) in human melanocytes and melanoma cells (Hedley et al, 1998b; Morandini et al, 1998) and reduce interactions between cytokine-stimulated melanoma cells and $\mathrm{T}$ lymphocytes (Hedley et al, 2000). The expression of inflammatory cytokines and adhesion receptors such as ICAM-1 are largely under the control of the transcription factor NF- $\kappa \mathrm{B}$ (Ghosh et al, 1998). We also found $\alpha-\mathrm{MSH}$ to reduce TNF- $\alpha$ stimulated NF- $\kappa \mathrm{B}$ activity (and oxidative stress) in keratinocyte and melanoma lines (Haycock et al, 1999, 2000), suggesting protection of the epidermis from inflammatory and oxidative stresses. In addition, B16 melanoma cells respond to $\alpha-\mathrm{MSH}$ with inhibition of growth and reduced adhesion (Robinson and Healy, 2002).

Melanocortin (MC) action arises via G-protein receptor signalling. Five receptors (MC-1R-MC-5R) have been cloned to date 
(Mountjoy et al, 1992) and MC-1R is expressed on human keratinocytes, melanocytes and melanoma cells (Donatien et al, 1992; De Luca et al, 1993; Bohm et al, 1999). Loss-of-function polymorphic variants exist (Valverde et al, 1995) and are associated with red-haired individuals who pigment poorly (Schiöth et al, 1999). Reports also suggest that MC-1R polymorphisms correlate with cutaneous melanoma (Box et al, 1997; JiménezCervantes et al, 2001), although not all studies have confirmed this (Ichii-Jones et al, 1998).

Melanoma patients show high levels of $\alpha$-MSH in plasma and tumours (Ghanem et al, 1989a,b), thought to correlate with malignant melanoma development (Liu and Johansson, 1995). However, $\alpha-\mathrm{MSH}$ is reported to both stimulate and inhibit melanoma invasion in vitro and in vivo. Murine melanoma cells respond to $\alpha-\mathrm{MSH}$ stimulation in vitro with a higher number of metastases in vivo, and a positive correlation exists between murine melanoma cell response to $\alpha$-MSH (assessed by cAMP elevation) in vitro and metastatic success in vivo (Sheppard et al, 1984; Hill et al, 1990). However, $\alpha$-MSH can inhibit B16-BL6 melanoma invasion through reconstituted (Matrigel) basement membrane (Murata et al, 1997), and reduce colony formation by $50 \%$, in agreement with similar work in B16-F10 cells (Kameyama et al, 1990). Thus, it is unclear if $\alpha$-MSH promotes or inhibits melanoma invasion, or if it is the immune response to melanoma.

As the role of $\alpha-\mathrm{MSH}$ in melanoma progression is unclear, and in light of additional cytoprotective roles, the aim of this study was to investigate the actions of $\alpha-\mathrm{MSH}$ on both melanoma cell invasion and the ability of $\alpha$-MSH to attenuate the response of cells to proinflammatory cytokines using human melanoma lines.

\section{MATERIALS AND METHODS}

\section{Materials}

Dulbecco's modified Eagle's medium (DMEM), glutamine, penicillin, streptomycin, amphotericin B, vitamin concentrate, Triton X 100 , newborn calf serum (NBCS), Ham's F10 and F12, nonessential amino acids (NEA) and trypsin/EDTA were from Gibco BRL, Paisley, UK. Dispase was from Difco Laboratories, Detroit, USA. Fetal calf serum (FCS) was from GlobePharm Ltd, Esher, UK. Phosphate-buffered saline (PBS) was from Oxoid Ltd, Basingstoke, UK. Transwell ${ }^{\mathrm{TM}}$ plates (24-well) were from Corning Costar Corporation, Cambridge, MA, USA. Collagenase A and TNF- $\alpha$ were from Boehringer Mannheim, Lewes, UK. Tri-iodothyramine, epidermal growth factor (EGF), hydrocortisone, adenine, insulin, transferrin, isobutyl methylxanthine (IBMX), MTT, N-(A-Rhamnopyranosyloxyhydroxy-phosphinyl)-leu-trp sodium (Phosphoramidon), RPMI-1640, sodium pyruvate, D-glucose, bovine serum albumin (BSA), Cell Dissociation Solution, human plasma fibronectin, (-)- $N^{6}$-(2-phenylisopropyl)-adenosine (PIA) and trypan blue were from Sigma Chemicals Ltd, Poole, UK. Paraformaldehyde, $\mathrm{NH}_{4} \mathrm{Cl}$, glycerol, circular glass coverslips and poly-Llysine-coated microscope slides were from BDH, Poole, UK. $\alpha$ Melanocyte-simulating hormone was from Bachem, Essex, UK. Primary goat polyclonal IgG-specific antibody to MC-1R (N-19) and MC-2R (C-16), and anti-NF- $\kappa \mathrm{B}$ (p65) goat polyclonal IgG were from Santa Cruz Biotechnology Inc., CA, USA. Biotinylated antigoat IgG and Streptavidin-FITC were from Vector Laboratories, Burlingame, USA. Fura-2-AM was from CN Biosciences, Beeston, UK. Prolong Antifade coverslip mounting medium was from Molecular Probes, Leiden, the Netherlands. Murine anti-HMB45 IgM was from Dako, Carpintera, USA. Bicinchoninic acid (BCA) assay kit was from Pierce (Tattenhall, Cheshire, UK). Enhanced chemiluminescence (ECL) kit was from AmershamPharmacia (Amersham, UK). Wizard kit and $\mathrm{TfX}^{\mathrm{TM}}-50$ Reagent were from Promega (Southampton, UK). pRc/CMV and geneticin (G-418) were from Invitrogen (Groningen, The Netherlands). All chemicals were of analytical grade unless otherwise indicated.

\section{METHODS}

\section{Keratinocyte cell culture}

Normal human skin keratinocytes were isolated as detailed previously (Chakrabarty et al, 1999; Eves et al, 2000). Freshly isolated cell suspensions were seeded onto dermal composites at $1 \times 10^{6}$ viable cells within a $1 \mathrm{~cm}^{2}$ stainless steel ring (see the section 'Reconstructed skin model of invasion' below for further details).

\section{Human fibroblast cell culture}

Dermal layers obtained after keratinocyte isolation were then used to isolate human skin fibroblasts (detailed in Chakrabarty et al, (1999); Eves et al, 2000). Fibroblast cells (passage 3-passage 9) were seeded onto dermal composites at $1 \times 10^{5}$ cells per composite ring (see the section 'Reconstructed skin model of invasion' below for further details).

\section{Human melanoma cell line culture}

Three human cutaneous melanoma cell lines were used: (i) HBL; (ii) A375-SM and (iii) C8161. HBL is derived from a lymph node metastasis of a nodular melanoma established in one of our laboratories (Ghanem et al, 1988). Cells were maintained as detailed in Eves et al (2000) and passaging was in 0.02\% EDTA. For composite experiments, HBLs were resuspended in keratinocyte culture medium (KCM); for invasion, attachment and proliferation assays, HBL cells were resuspended in serum-free invasion assay medium (SFIAM). For MC-1R and NF- $\kappa \mathrm{B}$ immunolabelling, and calcium and cyclic adenosine monophosphate (cAMP) experiments, HBLs were resuspended in Ham's F10 melanoma culture medium (HMCM). The A375-SM cell line was a generous gift from Professor IJ Fidler (USA) via Professor MJ Humphries (University of Manchester, UK). A375 was established in culture from a lymph node metastasis of a 54-year-old female (Giard et al, 1973). These cells are heterogeneous in nature and a highly metastatic variant (A375-SM) was established in culture from lung metastases produced by parental A375 cells growing subcutaneously in nude mice (Kozlowski et al, 1984). The C8161 melanoma line was kindly donated by Professor F Meyskens (University of California, Irvine, USA) via Professor M Edwards (University of Glasgow, UK). C8161 was established from an abdominal wall metastasis (Bregman and Meyskens, 1983). Both A375-SM and C8161 cells (and B16 F10C1 murine melanoma cells used as a positive control for measurement of cAMP) were cultured in Eagle's modified essential medium (EMEM) supplemented with $10 \%\left(\mathrm{vv}^{-1}\right) \mathrm{FCS}, 2 \mu \mathrm{M}$ L-glutamine, $100 \mathrm{IU} \mathrm{ml}^{-1}$ penicillin and $100 \mu \mathrm{g} \mathrm{ml}^{-1}$ streptomycin, $1.2 \mu \mathrm{g} \mathrm{ml}^{-1}$ amphotericin $\mathrm{B}, 1.5 \%\left(\mathrm{vv}^{-1}\right)(100 \times$ stock $)$ vitamin concentrate, $1 \times 10^{-3} \mathrm{moll}^{-1}$ sodium pyruvate, $1 \%\left(\mathrm{vv}^{-1}\right)$ NEA and $0.187 \%\left(\mathrm{vv}^{-1}\right)$ sodium hydrogen carbonate, and incubated at $37^{\circ} \mathrm{C}$ in humidified $5 \%$ carbon dioxide $/ 95 \%$ air. When approximately $80-90 \%$ confluent, cells were passaged using Cell Dissociation Solution. For invasion, attachment and proliferation assays, A375-SM and C8161 melanoma cells were resuspended in SFIAM, and for MC-1 receptor and NF- $\kappa \mathrm{B}$ immunolabelling and calcium and $\mathrm{cAMP}$ experiments, cells were resuspended in complete EMEM.

\section{Generation of a melanoma cell line with stable expression of $\mathrm{MC}-1$ receptor}

A stable C8161 melanoma cell line expressing functional MC-1 receptors was isolated by transfecting C8161 cells with vector pRc/ CMV carrying MC-1 cDNA (kindly donated by Professor JES 
Wikberg, Uppsala University, Sweden). Briefly, cells were plated in $100 \mathrm{~mm}$ dishes in complete EMEM media. After growth to approximately $70 \%$ confluence, the cells were transfected with $15 \mu \mathrm{g}$ of $\mathrm{pRC} / \mathrm{CMV} / \mathrm{MC}-1 \mathrm{DNA}$ using $\mathrm{Tfx}^{\mathrm{TM}}-50$ Reagent, according to the manufacturer's (Promega) protocol. Individual transfectants were isolated and cloned by limiting dilution following growth in complete EMEM media containing $500 \mu \mathrm{g} \mathrm{ml}^{-1}$ geneticin (G-418).

\section{Indirect immunofluorescent labelling of MC-1R and $\mathrm{NF} \kappa \mathrm{B} / \mathrm{p} 65$}

C8161 $\left(5 \times 10^{3}\right.$ cells ml $\left.{ }^{-1}\right)$ and A375-SM $\left(1 \times 10^{4}\right.$ cells ml $\left.^{-1}\right)$ cells were resuspended in EMEM, and HBL $\left(3 \times 10^{4} \mathrm{cells} \mathrm{ml}^{-1}\right)$ were resuspended in HMCM and seeded onto sterile circular glass coverslips (13 mm diameter) in 24-well plates and incubated at $37^{\circ} \mathrm{C}$ in humidified $5 \%$ carbon dioxide $/ 95 \%$ air until approximately $80-90 \%$ confluent. For the $\mathrm{NF} \kappa \mathrm{B} / \mathrm{p} 65$ studies, melanoma cells were incubated in the appropriate medium (HMCM/ EMEM $) \pm \alpha$-MSH $\left(10^{-12} 10^{-6} \mathrm{M}\right)$ for $15 \mathrm{~min}$, followed by a $1 \mathrm{~h}$ incubation in fresh medium $\pm \mathrm{TNF}-\alpha\left(300 \mathrm{U} \mathrm{ml}^{-1}\right)$. Cells were immunofluorescently labelled for $\mathrm{MC}-1 \mathrm{R}$ and $\mathrm{NF} \kappa \mathrm{B} / \mathrm{p} 65$ as detailed previously (Moustafa et al, 2002). Melanocortin-1 receptors and $\mathrm{NF} \kappa \mathrm{B} / \mathrm{p} 65$ in each melanoma were visualised using epifluorescent illumination (FITC filter, $\lambda_{\mathrm{ex}}=490 \mathrm{~nm}$, $\lambda_{\mathrm{em}}=523 \mathrm{~nm}$ ), and nuclei were visualised using a rhodamine filter $\left(\lambda_{\mathrm{ex}}=555 \mathrm{~nm}, \lambda_{\mathrm{em}}=580 \mathrm{~nm}\right)$ with a Nikon X600 microscope. Digital images of $\mathrm{MC}-1 \mathrm{R} / \mathrm{NF} \kappa \mathrm{B} / \mathrm{p} 65$ and nuclei were captured and overlaid using Adobe Photoshop. Cellular movement of NF- $\kappa \mathrm{B} / \mathrm{p} 65$ was evaluated as described previously (Moustafa et al, 2002).

\section{Western blotting for MC-1R and MC-2R}

Melanoma cells were seeded into six-well plates at $10^{5}$ cells per well and grown until $60 \%$ confluent. Western blot analysis was carried out as detailed previously (Moustafa et al, 2002). Immunoreactive bands were visualized using an ECL kit.

\section{MSH receptor binding studies}

Saturation and competitive binding assays were performed using the following modification of a previously published method (Ghanem et al, 1988). Saturation assays allowed calculation of total receptor numbers and competitive binding allowed calculation of the affinity of the receptors for the peptide. Briefly, $250 \times 10^{3}$ d.p.m. of ${ }^{125} \mathrm{I}-\left[\mathrm{Nle}^{4}, \mathrm{Dphe}^{7}\right]-\alpha-\mathrm{MSH}$ in $100 \mu \mathrm{l}$ was added to $10^{6}$ cells $(100 \mu \mathrm{l})$ previously mixed with $\left[\mathrm{Nle}^{4}, \mathrm{Dphe}^{7}\right]-\alpha-\mathrm{MSH}$ (concentration ranging from $10^{-12}$ to $10^{-6} \mathrm{M}$ ) in PBS $\mathrm{pH} 7.2$ containing $0.1 \% \mathrm{BSA}, 6.25 \mathrm{~mm}$ Hepes and $0.1 \%$ trasylol. After mixing, the tubes were incubated at $37^{\circ} \mathrm{C}$ for $45 \mathrm{~min}$ before cell separation by repeated centrifugation and washing. The pelletassociated radioactivity was then measured in a gamma counter.

\section{DNA extraction, amplification and sequencing of MC-1R}

Briefly, genomic DNA was extracted from the HBL, C8161 and A375-SM cell lines using a Wizard kit. The full-length coding sequence of the $M C-1 R$ gene was amplified using primers as detailed previously (Jiménez-Cervantes et al, 2001).

\section{Measurement of intracellular free calcium}

Cells were grown as monolayers on glass coverslips until nearly confluent and incubated with $4 \mu \mathrm{M}$ Fura-2 AM for $15 \mathrm{~min}$ at $37^{\circ} \mathrm{C}$. Cells were then washed with balanced salt solution $(1.5 \mathrm{~mm}$ calcium chloride, $0.5 \mathrm{~mm}$ magnesium chloride, $135 \mathrm{~mm}$ sodium chloride, $4.5 \mathrm{~mm}$ potassium chloride, $5.6 \mathrm{~mm}$ glucose, $10 \mathrm{~mm}$ Hepes, $\mathrm{pH} 7.4$ ), and coverslips of cells were examined in a fluorimeter (Kontron SKM 25) to determine changes in intracellular calcium in response to the adenosine agonist PIA $(10 \mu \mathrm{M})$, and $\alpha$-MSH $\left(10^{-12} \mathrm{M}\right.$ to $10^{-6} \mathrm{M}$ ) alone or in combination. Details are as previously described in Metcalfe et al (1998).

\section{Measurement of cAMP}

Both intracellular and extracellular cAMP responses to peptide addition were examined. For intracellular cAMP, cells were prelabelled with tritiated adenosine for $2 \mathrm{~h}$. Cells were then preincubated with $0.8 \mathrm{mM}$ IBMX for $15 \mathrm{~min}$ prior to addition of $\alpha$-MSH at a range of concentrations for $10 \mathrm{~min}$. Cells were washed with PBS, $100 \mu$ l ethanol was added and the cells were stored at $-20^{\circ} \mathrm{C}$. Assay details are as previously described (Metcalfe et al, 1998). Extracellular cAMP in the media was determined using a commercially available kit (Biomedical Technologies Inc., USA), in which cAMP measurement is based on competitive binding between CAMP and an alkaline phosphate derivative of cAMP for a limited amount of specific antibody. A secondary antibody separates the bound CAMP from the free cAMP. A coloured end product is determined using a microtitre plate reader, measuring absorbance at $405-410 \mathrm{~nm}$. Results shown are of three separate experiments.

\section{Fibronectin invasion assay}

Transwell $^{\mathrm{TM}}$ inserts were coated with a layer of human fibronectin as described previously (Dewhurst et al, 1997), and placed onto a 24-well tissue culture plate containing $600 \mu \mathrm{l}$ SFIAM (RPMI-1640 medium supplemented with $20 \mathrm{ng} \mathrm{ml}^{-1}$ EGF, 0.2\% $\left(\mathrm{wv}^{-1}\right)$ Dglucose solution and $\left.0.1 \%\left(\mathrm{w} \mathrm{v}^{-1}\right) \mathrm{BSA}\right)$. Cell suspensions $(50 \mu \mathrm{l}$ containing $0.6 \times 10^{5} \mathrm{~A} 375-\mathrm{SM}$ cells or $1.2 \times 10^{5} \mathrm{HBL} / \mathrm{C} 8161$ cells in SFIAM) plus an equivalent volume of SFIAM ( \pm pharmacological agent) were added to each insert and cells were incubated for 15$52 \mathrm{~h}$ at $37^{\circ} \mathrm{C}$ in $5 \% \mathrm{CO}_{2} / 95 \%$ air. As cell lines invaded at different rates, HBL cells were cultured for $20 \mathrm{~h}$ (Dewhurst et al, 1997; Richardson et al, 1999), C8161 cells for $15 \mathrm{~h}$ and A375-SM cells for $52 \mathrm{~h}$, to obtain comparable levels of invasion. For the $52 \mathrm{~h}$ incubation time, a cell density of $0.6 \times 10^{5}$ cells was used. After incubation, medium (containing cells) was collected from the upper and lower compartments of the Transwell ${ }^{\mathrm{TM}}$ chamber and placed into preweighed LP4 perspex tubes. The medium removed was replaced with an equivalent volume of $0.1 \%\left(\mathrm{wv}^{-1}\right)$ trypsin and $0.02 \%\left(\mathrm{w} \mathrm{v}^{-1}\right)$ EDTA and the cells were incubated $(10 \mathrm{~min}$, $37^{\circ} \mathrm{C}$ ). Trypsin (plus cells) was removed and placed in samplematched tubes and a second trypsin incubation, followed by gentle scraping of the polycarbonate filter surface (upper chamber) and the undersides of each polycarbonate filter as well as the tissue culture plastic of the lower chambers, ensured that all the cells were harvested. Cells were centrifuged $(200 \mathrm{~g}, 5 \mathrm{~min})$, the majority of supernatant removed and tubes reweighed. Cells from each tube were resuspended in the remaining medium and the cell numbers counted using a haemocytometer. Noninvading cells were those remaining in the Transwell ${ }^{\mathrm{TM}}$ upper chamber and those attached to the upper surface of the filter. Invading cells were those removed from the underside of the filter, suspended in the medium of the tissue culture wells and attached to the base of the 24-well chamber (cells collected into the lower tubes). A combined analysis of cell counts plus obtained weight/volume for each cell suspension (weight of tubes containing cell suspensions minus the weight of empty tubes) provided a percentage of the total population of cells that had invaded through fibronectin. (This 'total housekeeping' approach to counting all cells is an improvement on the assay first described by us (Dewhurst et al, 1997)).

\section{Reconstructed skin model of invasion}

Full details have been described previously (Chakrabarty et al, 1999; Eves et al, 2000). Briefly, sterile human skin was rehydrated 
in PBS and incubated in $1 \mathrm{M} \mathrm{NaCl}$, which resulted in a deepidermised acellular dermis (DED) with retained basement membrane antigens. Dermal fibroblast cells $\left(1 \times 10^{5}\right)$ were added to the reticular DED surface. After $48 \mathrm{~h}$, HBL melanoma cells $\left(5 \times 10^{4}\right)$ and epidermal keratinocytes $\left(1 \times 10^{6}\right)$ were added to the papillary DED surface. HBL melanoma cells were seeded $4 \mathrm{~h}$ before keratinocytes. After $48 \mathrm{~h}$, the reconstructed skin composites were raised to an air-medium interface containing $\alpha$-MSH $\left(1 \times 10^{-9} \mathrm{M}\right) / \operatorname{IBMX}(50 \mu \mathrm{M})$ or medium alone (control). Composites were cultured for 2 weeks and the culture medium was changed every $2-3$ days $\left( \pm \alpha\right.$-MSH $\left(1 \times 10^{-9}\right.$ M)/IBMX $\left.(50 \mu \mathrm{M})\right)$. External appearance of the upper surface of the composites was documented by photography prior to fixing in formalin. Paraffinfixed histology sections $(10 \mu \mathrm{m})$ were made for haematoxylin and eosin staining and for immunolabelling of HMB45 for the identification of HBL melanoma cells (previously described in Eves et al, 2000). To assess the extent of invasion, a semiquantitative scoring system of $0-3$ was used. Sections through the centre of the $1 \mathrm{~cm}$ diameter composite were examined for invasion of HBL cells. In each case, a score of 0 (zero) represented composites where no melanoma cells were present in the dermis. A score of 0.5 represented $1-5$ cells in the dermis, $1.0,6-15$ cells in the dermis. A score of 1.5 represented 16-20 cells in the dermis, 2.0, 21-30 cells in the dermis and 2.5, 31-40 cells in the dermis. A score of 3.0 was reserved for florid invasion into the dermis where there were too many cells to count $(+50$ cells $)$.

\section{Statistics}

Student's paired $t$-test was used to analyse data where identical cellular treatments were present as a continuous series and where the only variable involved was the concentration of peptide or drug used. Nonparametric Mann-Whitney $U$-test was used to assess differences in the invasion of melanoma cells in a skin model containing several variables.

\section{RESULTS}

\section{Melanocortin-1 and MC-2 receptor expression}

All three melanoma cells were observed to label positively, albeit weakly, for MC-1R as identified by immunofluorescent microscopy (Figure 1A). HEK293 cells (which do not express MC-1R) did not label, as confirmed previously (Moustafa et al, 2002). No immunoreactivity was observed for cells incubated with isotype control serum. Western immunoblotting using the same primary anti-MC-1R antibody revealed a reactive band at $35 \mathrm{kDa}$ molecular mass for the HBL, A375-SM and C8161 melanoma cell lines (Figure $1 \mathrm{~B})$; close to the predicted size of MC-1R, based on sequencing information (Mountjoy et al, 1992). The extracts of HEK293 cells did not reveal a similar band. Western blotting using a primary anti-MC-2R antibody revealed a reactive band at $39 \mathrm{kDa}$ molecular mass for the HBL and A375-SM cell lines, but not in C8161 cells (Figure 1B). Higher molecular weight bands were also observed for both MC-1 and MC-2 receptors, indicating crossreactivity of the polyclonal sera used.

\section{Melanocortin receptor binding}

Receptor saturation studies demonstrated that HBL melanoma cells (as previously noted) had around 1000-3000 binding sites per cell and C8161 cells had around 400 receptors per cell (Figure $2 \mathrm{~A}$ and $\mathrm{B})$. The receptor number for the A375-SM cell line was much lower and not statistically different to the level of nonspecific binding achieved (Figure 2). The three cell lines demonstrated similar binding affinities for $\alpha$-MSH (summarised in Figure 2B). However, caution must be used in considering the binding affinity

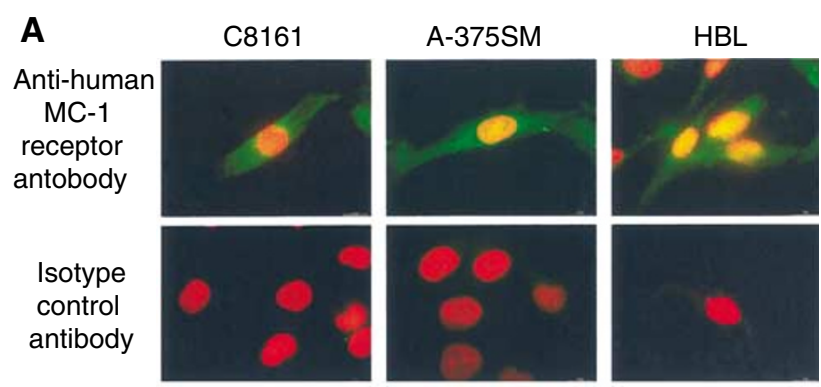

B
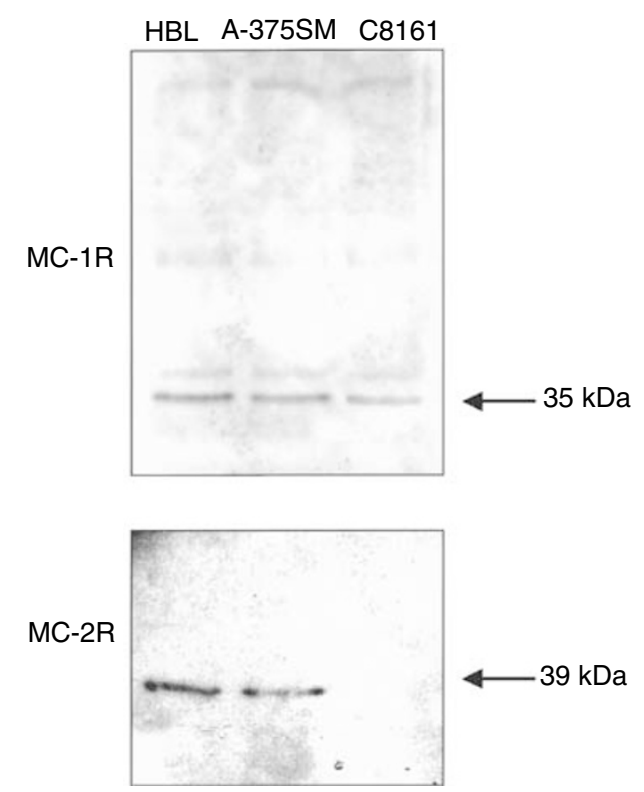

Figure I (A) Upper micrographs: Presence of MC-I receptors on HBL, A375-SM and C816I melanoma cell lines. Melanocortin-I receptors (green fluorescence) were visualised using epifluorescent illumination (FITC filter, $\lambda_{\mathrm{ex}}=490 \mathrm{~nm}, \lambda_{\mathrm{em}}=523 \mathrm{~nm}$ ) and nuclei (red fluorescence) were visualised with a rhodamine filter $\left(\lambda_{\mathrm{ex}}=555 \mathrm{~nm}, \lambda_{\mathrm{em}}=580 \mathrm{~nm}\right)$. Lower micrographs: Corresponding cell lines using isotype control primary antibody demonstrating observed specificity of immunolabelling. Bar $=20 \mu \mathrm{m}$. (B) Western blotting of HBL, A375-SM and C8161 melanoma cell lines for MC-I and $M C-2$ receptors.

for the A375-SM due to a relatively low number of receptors expressed per cell.

\section{Melanocortin-1 receptor sequences}

Sequencing of the MC-1R genomic DNA revealed the HBL melanoma line to be homozygous wild type, the A375-SM line to contain a homozygous polymorphism for Arg151Cys, while the C8161 line was heterozygous for Arg151Cys, with the other allele displaying a wild type sequence.

\section{$\alpha$-Melanocyte stimulating hormone, cAMP and intracellular calcium}

The human HBL and murine B16F10-C1 melanoma cell line (used as a positive control) responded to $\alpha-\mathrm{MSH}$ concentrations from $10^{-13}$ to $10^{-6} \mathrm{M}$ with increasing cAMP (Figure $3 \mathrm{~A}$ and $\mathrm{B}$ ). The C8161 and A375-SM melanoma cells did not respond to any concentrations of $\alpha$-MSH with a detectable level of either extracellular or intracellular cAMP (Figure 3A and 3B). However, HBL (Figure 4 (1)), A375-SM (Figure 4 (2)) and C8161 (Figure 4 (3)) melanoma cells all responded with increases in intracellular 

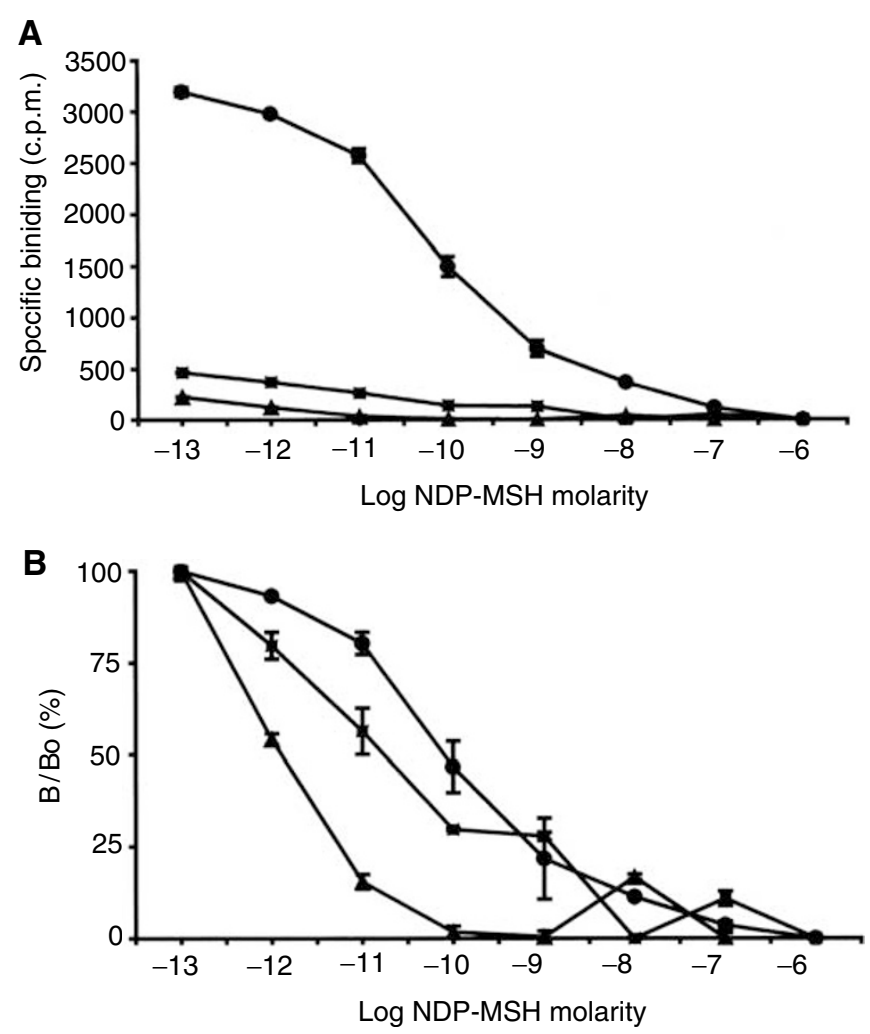

Figure 2 (A) Competitive binding of $\alpha-M S H$ for radiolabelled Nle4DPhe7-MSH was performed to saturation showing displacement data for HBL, A375-SM and C8I 6 I melanoma cells, allowing calculation of total receptor numbers. (B) Competitive binding data was used to determine the affinity of melanoma cells for $\alpha-M S H$ (circles, HBL; squares, C8161; triangles, A375-SM; means \pm s.e.m., $n=3$ ).

calcium to $\alpha$-MSH + PIA addition at concentrations of $\alpha$-MSH from $10^{-13} \mathrm{M}$ to $10^{-6} \mathrm{M}$. Increases in intracellular calcium were only ever observed in the presence of $10 \mu \mathrm{M}$ PIA (a pharmacological adenosine agonist that inhibits any elevation of cAMP). $\left(+(-)-N^{6}-(2-\right.$ phenylisopropyl)-adenosine alone did not elevate calcium in any of the cell lines (results not shown). It was observed that the magnitude of the response obtained for the C8161 melanoma line (Figure 4 (3)) was consistently greater than that observed for the HBL or A375-SM lines (Figure 4 (1 or 2)). A summary of intracellular calcium responses is given in Table 1.

\section{$\alpha$-Melanocyte-simulating hormone and the invasion of melanoma cells through human fibronectin}

As the three melanoma cell lines invaded through the fibronectinTranswell $^{\mathrm{TM}}$ layer at different rates, the invasion assay incubation time was adjusted to obtain a reproducible number of cells invading under basal control conditions, equivalent to between 20 and $50 \%$ of total cell number. The C8161 melanoma cell line was highly invasive with $49 \pm 6.8 \%$ of the total cell population invading after $15 \mathrm{~h}(n=5)$. In contrast, the HBL melanoma cell line gave invasion of $42 \pm 2 \%(n=10)$ after $20 \mathrm{~h}$ and A375-SM cells were the least invasive with $20 \pm 2.6 \%$ of the total cell population invading after $52 \mathrm{~h}(n=7)$.

Using the above experimental conditions, $\alpha$-MSH significantly inhibited invasion of the HBL melanoma cells through fibronectin (results are presented as the mean percentage of invasion found in the control), in a concentration-dependent manner (Figure 5A). A maximum inhibition of $58 \%$ for HBL cells was observed using $10^{-7} \mathrm{M} \alpha$-MSH. For A375-SM melanoma cells, relatively low
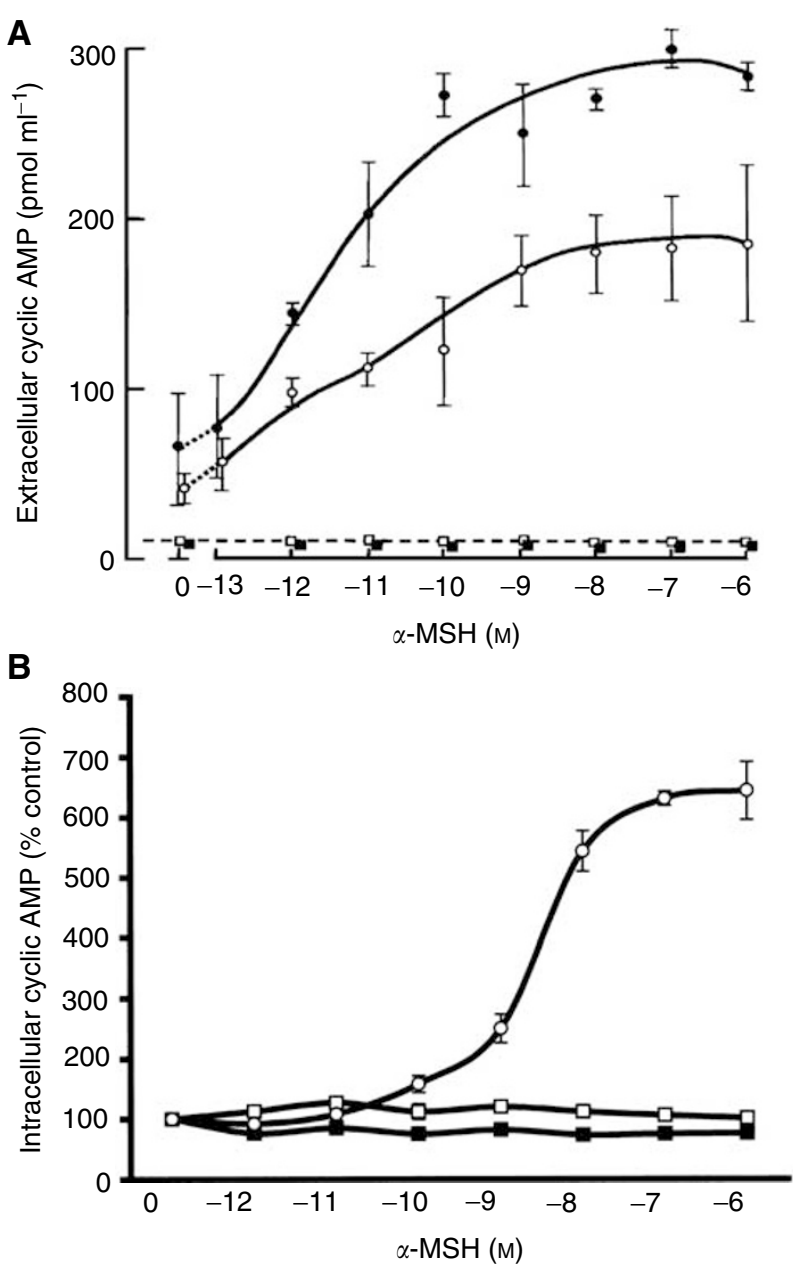

Figure 3 Detection of extracellular $(\mathbf{A})$ and intracellular (B) cAMP in response to increasing concentrations of $\alpha-M S H$. Symbols: filled circles, mouse melanoma $\mathrm{Bl} 6 \mathrm{FIOCl}$ (positive control); open circles, HBL melanoma cells; filled squares, A375-SM melanoma cells; open squares, C816I melanoma cells (means \pm s.e.m., $n=3$ )

concentrations of $\alpha$-MSH $\left(10^{-12}-10^{-10} \mathrm{M}\right)$ were observed to significantly inhibit invasion with $10^{-12} \mathrm{M}$, demonstrating $46 \%$ inhibition (Figure 5B). Interestingly, $\alpha$-MSH concentrations above $10^{-9} \mathrm{M}$ were ineffective in inhibiting invasion of this cell line. In contrast, $\alpha$-MSH had no effect on the invasive ability of C8161 cells through human fibronectin (Figure 5C). However, when these cells were stably transfected with the wild-type MC-1R, $\alpha$-MSH (at $\left.10^{-7} \mathrm{M}\right)$ inhibited invasion by approximately $30 \%(72 \pm 1.9 \%$, $n=4, P<0.0006$, Figure 5D). With the HBL melanoma cells, the inhibitory effect of $\alpha-\mathrm{MSH}$ was confirmed to be via a cAMP mechanism by using the receptor-independent agents, IBMX and forskolin. Table 2 shows that IBMX (at $5 \times 10^{-4} \mathrm{M}$ ) significantly inhibited HBL melanoma cell invasion by $70 \%$ and forskolin (at $1 \times 10^{-4} \mathrm{M}$ ) inhibited invasion by $59 \%$. For A375-SM cells, the largest inhibition of invasion observed was with $1 \times 10^{-4} \mathrm{M} \mathrm{IBMX}$ $(36 \%)$ or $1 \times 10^{-5} \mathrm{M}$ forskolin (39\%), but neither results were statistically significant. A cAMP mechanism was also confirmed for the C8161 melanoma cell line, as cell invasion was inhibited by $1 \times 10^{-5} \mathrm{M}(21 \%)$ and $1 \times 10^{-6} \mathrm{M}(53 \%)$ forskolin. Furthermore, combination of $\alpha$-MSH $\left(1 \times 10^{-9} \mathrm{M}\right)$ and IBMX $\left(5 \times 10^{-5}\right.$ and $\left.1 \times 10^{-4} \mathrm{M}\right)$ with $\mathrm{HBL}$ melanoma cells resulted in a further significant reduction in HBL invasion, compared to either $\alpha$ MSH or IBMX alone (Table 3). However, no further reduction in 
(1)
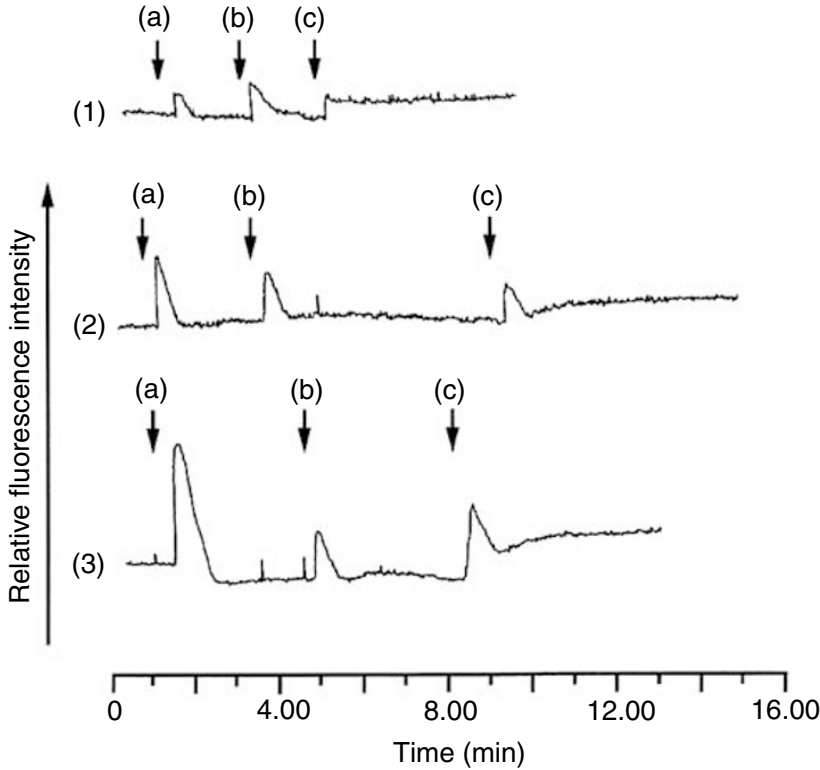

Figure 4 Intracellular calcium responses of (I) HBL (2) A375-SM and (3) C8|6I melanoma cells to $\alpha-M S H+P I A ~(I 0 \mu M)$. Cells were loaded with Fura-2 AM and the intracellular calcium release was detected by optical fluorimetry. $+(-)-N^{6}$-(2-phenylisopropyl)-adenosine was always added at the same time as $\alpha-\mathrm{MSH}$ indicated by position of individual vertical arrows. (a) $\alpha-M S H\left(10^{-11} \mathrm{M}\right)$; (b) $\alpha-\mathrm{MSH}\left(10^{-9} \mathrm{M}\right)$ and (c) $\alpha-M S H\left(I 0^{-7} M\right)$.

Table I Summary of the number of observed positive responses to $\alpha$ $\mathrm{MSH}+\mathrm{PIA}(10 \mu \mathrm{M})$ in inducing an intracellular calcium signal in $\mathrm{HBL}, \mathrm{A} 375$ SM and C8I6I melanoma cells

\begin{tabular}{lccc}
\hline & \multicolumn{3}{c}{$\begin{array}{c}\text { Number of coverslips responding with an } \\
\text { increase in calcium }\end{array}$} \\
\cline { 2 - 4 } $\begin{array}{l}\boldsymbol{\alpha} \text {-MSH (M)+PIA } \\
(\mathbf{1 0} \boldsymbol{\mu M})\end{array}$ & HBL & A375-SM & $\mathbf{C 8 1 6 1}$ \\
\hline $10^{-13} \mathrm{M}$ & $3 / 6$ & $6 / 6$ & $2 / 2$ \\
$10^{-12} \mathrm{M}$ & $5 / 6$ & $6 / 6$ & $1 / 1$ \\
$10^{-11} \mathrm{M}$ & $9 / 9$ & $7 / 7$ & $4 / 4$ \\
$10^{-10} \mathrm{M}$ & $6 / 6$ & $6 / 6$ & $3 / 3$ \\
$10^{-9} \mathrm{M}$ & $6 / 6$ & $6 / 6$ & $5 / 5$ \\
$10^{-8} \mathrm{M}$ & $6 / 6$ & $6 / 6$ & $5 / 5$ \\
$10^{-7} \mathrm{M}$ & $6 / 6$ & $7 / 7$ & $4 / 4$ \\
$10^{-6} \mathrm{M}$ & $6 / 6$ & $10 / 10$ & $6 / 6$ \\
\hline
\end{tabular}

invasion was observed when forskolin $\left(1 \times 10^{-4} \mathrm{M}\right)$ was combined with $\alpha$-MSH $\left(1 \times 10^{-9} \mathrm{M}\right)$, in comparison to either agent alone.

\section{$\alpha$-Melanocyte-simulating hormone and melanoma cell invasion through reconstructed skin}

A more clinically relevant model of human reconstructed skin (detailed in Eves et al, 2000) was used to investigate the actions of $\alpha$-MSH on invasion of the HBL melanoma cell line. The other two cell lines were not investigated using this model, as they had shown limited (A375SM) or no (C8161) response to $\alpha-\mathrm{MSH}$ in the fibronectin invasion model. A midrange inhibitory concentration of $1 \times 10^{-9} \mathrm{M} \alpha$-MSH was used. In order to potentiate $\alpha$-MSH in this model, it was also combined with $5 \times 10^{-5} \mathrm{M}$ IBMX. Addition of $\alpha$-MSH/IBMX had no obvious effect on the pigmentation of the HBL cells (Figure 6A-C) in this skin model and did not affect the gross morphology of the composites; however, it did affect HBL dendricity (results not shown).

\section{A}

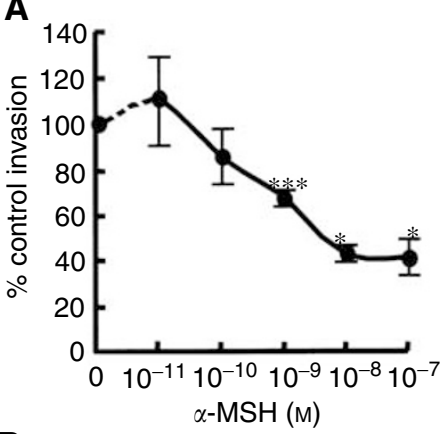

B

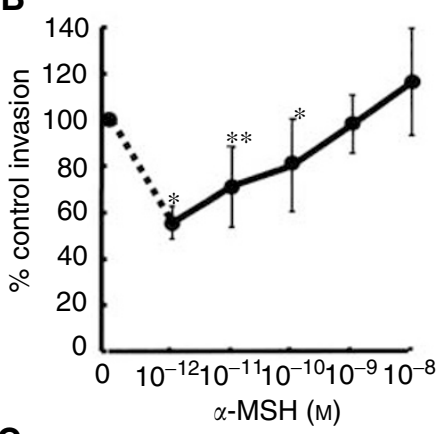

C

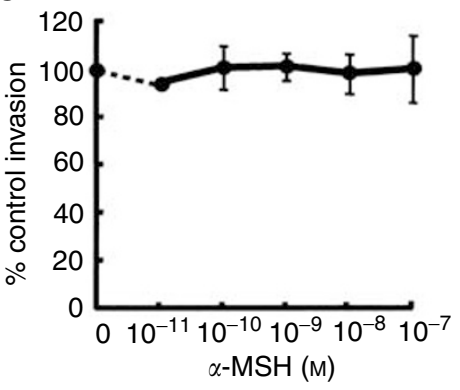

D

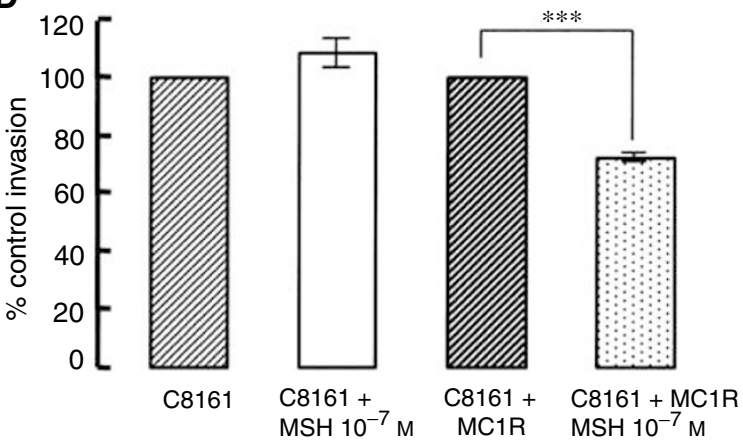

Figure 5 Effect of $\alpha-M S H$ on melanoma invasion through human fibronectin. The invasion assay was run for (A) $20 \mathrm{~h}$ with $\mathrm{HBL}$ melanoma cells, (B) $52 \mathrm{~h}$ with A375-SM cells, (C) I5 h with C8I6I cells and (D) $15 \mathrm{~h}$ with untransfected and stably transfected (with MC-IR) C8I6I cells. Values shown represent the raw data (\% mean invasion) obtained for each experiment, which were normalised by relating all values to the control level of invasion in each individual experiment (taken as 100\%). Statistical comparison is made between invasion in the absence (control) and presence of $\alpha-\mathrm{MSH} .{ }^{*} P<0.05,{ }^{* *} P<0.01,{ }^{* * *} P<0.001$.

After a 2-week culture period where the composites were routinely fed with fresh media containing $\alpha$-MSH $\left(1 \times 10^{-9} \mathrm{M}\right)$ and IBMX $\left(5 \times 10^{-5} \mathrm{M}\right)$ every 3-4 days, they were sectioned and immunohistochemically labelled with an antibody to HMB45. Visual analysis of these sections clearly demonstrated that compared to control composites (Figure $7 \mathrm{~A}, \mathrm{C}, \mathrm{E}$ ), $\alpha$-MSH/IBMX 
Table 2 Summary of the effect of $\alpha-M S H$, IBMX, forskolin on the invasion of melanoma cells through human fibronectin

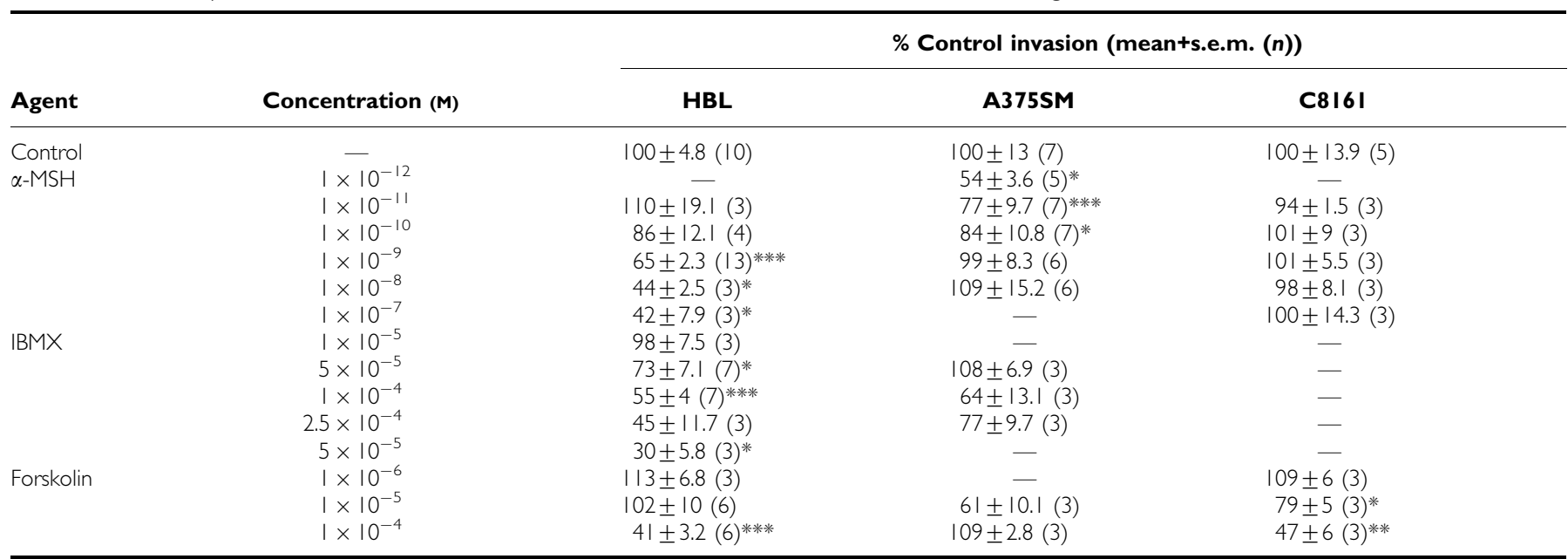

Statistical comparison is made between invasion in the absence (control) and presence of pharmacological agent. ${ }^{*} P<0.05,{ }^{* *} P<0.01,{ }^{* * *} P<0.00 \mathrm{I}$.

Table 3 Summary of the effect of $\alpha-M S H$, IBMX, forskolin and $\mathrm{H} 89$ on the invasion of $\mathrm{HBL}$ melanoma cells through human fibronectin

\begin{tabular}{lc}
\hline Agent(s) & $\begin{array}{c}\text { \% Control invasion of HBL cells } \\
\text { (mean } \pm \text { s.e.m. }(\boldsymbol{n}) \text { ) }\end{array}$ \\
\hline Control & $100 \pm 4.8(13)$ \\
$\alpha-M S H\left(10^{-9} \mathrm{M}\right)$ & $65 \pm 2.3(13)^{* * * * *}$ \\
IBMX $\left(5 \times 10^{-5} \mathrm{M}\right)$ & $73 \pm 7.1(7)^{*}$ \\
IBMX $\left(10^{-4} \mathrm{M}\right)$ & $55 \pm 4(7)^{* * * * *}$ \\
$\alpha-M S H\left(10^{-9} \mathrm{M}\right)+\mathrm{IBM} \times\left(5 \times 10^{-5} \mathrm{M}\right)$ & $48 \pm 7.4(3)^{*}$ \\
$\alpha-M S H\left(10^{-9} \mathrm{M}\right)+\mathrm{IBMX}\left(10^{-4} \mathrm{M}\right)$ & $35 \pm 5.9(4)^{* * * *}$ \\
Forskolin $\left(10^{-5} \mathrm{M}\right)$ & $102 \pm 10(6)$ \\
Forskolin $\left(10^{-4} \mathrm{M}\right)$ & $41 \pm 3.2(6) * * *$ \\
$\alpha-M S H\left(10^{-9} \mathrm{M}\right)+$ forskolin $\left(10^{-5} \mathrm{M}\right)$ & $101 \pm 15.9(3)$ \\
$\alpha-M S H\left(10^{-9} \mathrm{M}\right)+$ forskolin $\left(10^{-4} \mathrm{M}\right)$ & $39 \pm 2.2(3)^{* * *}$ \\
\hline
\end{tabular}

Statistical comparison is made between invasion in the absence (control) and presence of pharmacological agent. ${ }^{*} P<0.05,{ }^{* *} P<0.01,{ }^{* * * *} P<0.001$

(Figure $7 \mathrm{~B}, \mathrm{D}, \mathrm{F}$ ) had inhibited HBL invasion into the dermis. Semiquantitative analysis (see Figure 6D) was used to assess the extent of HBL invasion in the presence and absence of $\alpha-\mathrm{MSH} /$ IBMX. Extensive invasion in the absence of $\alpha$-MSH/IBMX was observed in 22 out of 23 composites, while invasion in the presence of $\alpha$-MSH/IBMX was only observed in 15 out of 25 composites. The overall inhibition was 59\% $(P<0.0005)$.

\section{$\alpha$-Melanocyte-simulating hormone and cytokine-induced activation of $\mathrm{NF} \kappa \mathrm{B} / \mathrm{p} 65$ in melanoma cells}

$\mathrm{NF}-\kappa \mathrm{B}$ translocation from the cytoplasm into the nucleus was observed for all melanoma lines (HBL, A375-SM, C8161) in response to stimulation with TNF- $\alpha$ (60 min; shown for A375-SM, Figure 8). Control untreated melanoma cells showed no evidence of NF- $\kappa$ B activity (Figure $8 \mathrm{~A}$ ). After 1 -h incubation with TNF- $\alpha$ $\left(300 \mathrm{U} \mathrm{ml}^{-1}\right), 85 \%$ of A375-SM cells showed an increase in activation (Figures $8 \mathrm{~B}$ and 9B). Addition of $\alpha$-MSH alone $\left(10^{-12}-10^{-8} \mathrm{M}\right)$ had no effect (Figure $8 \mathrm{C}$ and $\left.9 \mathrm{~B}\right)$; however; a $15 \mathrm{~min}$ preincubation $\left(10^{-12}-10^{-8} \mathrm{M}\right)$ followed by a $1 \mathrm{~h}$ stimulation with TNF- $\alpha\left(300 \mathrm{U} \mathrm{ml}^{-1}\right)$ resulted in a significant, concentrationdependent inhibition of TNF- $\alpha$-induced $\mathrm{NF} \kappa \mathrm{B} / \mathrm{p} 65$ activation (Figures $8 \mathrm{D}$ and $9 \mathrm{~B}$ ). HBL cells displayed $97 \%$ NF- $\kappa \mathrm{B}$ activation in response to TNF- $\alpha$. Addition of $\alpha$-MSH alone $\left(10^{-9} 10^{-6} \mathrm{M}\right)$ had no effect, but preincubation with $\alpha$-MSH $\left(10^{-9}-10^{-6} \mathrm{M}\right)$ for $15 \mathrm{~min}$ followed by a $1 \mathrm{~h}$ stimulation with TNF- $\alpha\left(300 \mathrm{U} \mathrm{ml}^{-1}\right)$ resulted in a concentration-dependent inhibition of TNF- $\alpha$ stimulated activity (Figure 9A). C8161 cells also had inactive NF- $\kappa$ B in the absence of stimulators. Treatment with TNF- $\alpha\left(300 \mathrm{U} \mathrm{ml}^{-1}\right)$ for $1 \mathrm{~h}$ activated NF- $\kappa \mathrm{B}$ to $88 \%$ of cells (Figure 9C). Addition of $\alpha-\mathrm{MSH}$ alone $\left(10^{-9} \mathrm{M}\right.$ to $\left.10^{-6} \mathrm{M}\right)$ resulted in a very slight but not significant increase in NF- $\kappa$ B activity (Figure $9 \mathrm{C}$ ). Preincubation of the C8161 cell line with $\alpha$-MSH $\left(1 \times 10^{-9}-1 \times 10^{-6} \mathrm{M}\right)$ followed by a $1 \mathrm{~h}$ stimulation with TNF- $\alpha\left(300 \mathrm{U} \mathrm{ml}^{-1}\right)$ only inhibited $\mathrm{NF} \kappa \mathrm{B} / \mathrm{p} 65$ activation by around $10-15 \%$. This was demonstrated to be marginally significant $(P<0.05)$, but compares poorly to the $70 \%$ inhibition of $\alpha-\mathrm{MSH}$ on HBL cells, and 35\% inhibition on A375-SM cells.

\section{DISCUSSION}

The aim of this study was to find out more about the role of $\alpha$-MSH in influencing melanoma progression. We compared three genetically distinct human melanoma cell lines and examined to what extent $\alpha$-MSH influenced cell invasion through a fibronectin protein layer and (for one of the lines) through a reconstructed skin model. The results obtained were compared with the ability of $\alpha-\mathrm{MSH}$ to inhibit proinflammatory cytokine TNF- $\alpha$ activation of $\mathrm{NF}-\kappa \mathrm{B}$, elevate cAMP and stimulate intracellular calcium. The main findings of this study were that while all three lines expressed MC-1R, they differed markedly in their response to $\alpha-M S H$. For HBL cells, which express wild-type MC1R, $\alpha$-MSH elevated intracellular and extracellular CAMP, induced an increase in intracellular calcium, was very effective at inhibiting invasion of cells through fibronectin and through a reconstructed skin model and also attenuated the response of the cells to TNF- $\alpha$. The A375SM cells were homozygous for Arg151Cys for the MC-1R, and responded partially in that $\alpha-\mathrm{MSH}$ inhibited invasion and the response to TNF- $\alpha$ at low $\alpha$-MSH concentrations, but with negligible responses at higher concentrations. $\alpha$-Melanocytesimulating hormone induced intracellular calcium levels but did not elevate intracellular or extracellular cAMP to detectable levels. C8161 cells were heterozygous Arg151Cys for MC-1R, and were unresponsive to $\alpha$-MSH with inhibiting invasion, had a small inhibitory response to TNF- $\alpha$ and failed to elevate intracellular or extracellular cAMP (although intracellular calcium responses were detected). However, stable transfection of these cells with the wildtype MC-1R showed that these cells were then able to respond to $\alpha$ $\mathrm{MSH}$ with a significant reduction in invasion. 
A

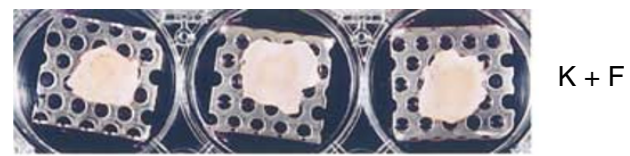

B

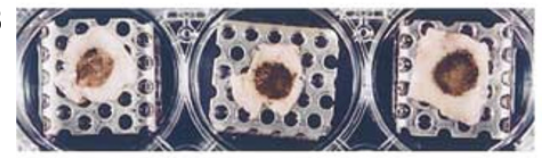

$\mathrm{K}+\mathrm{F}+\mathrm{HBL}$

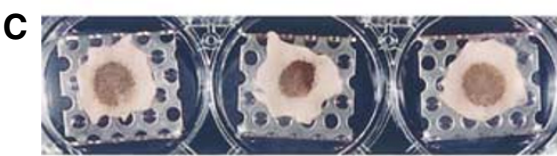

$\mathrm{K}+\mathrm{F}+\mathrm{HBL}$ $\alpha-\mathrm{MSH} / \mathrm{IBMX}$

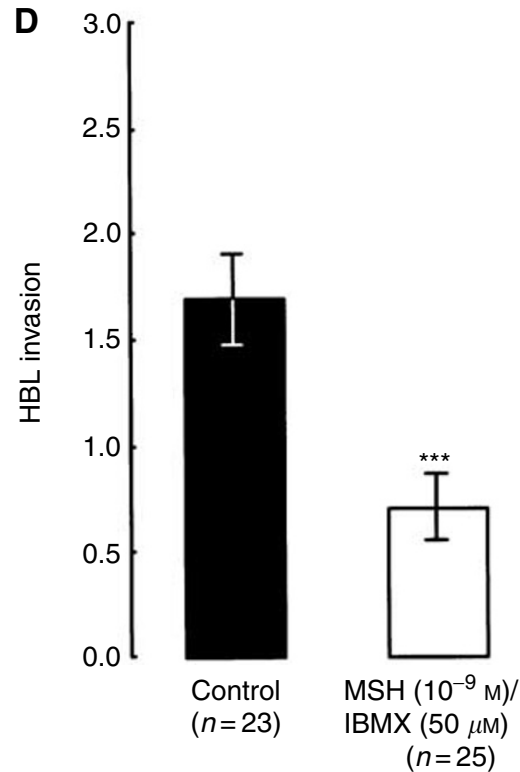

Figure 6 Melanoma cell invasion through reconstructed skin. Morphology (A-C) of composites and the extent of HBL invasion (D) through reconstructed skin $\pm \alpha-M S H / / B M X$. In $(\mathbf{A})$ composites contain keratinocytes $(\mathbf{K})$ and fibroblast $(\mathbf{F})$ cells; in $(\mathbf{B})$ composites contain keratinocytes, fibroblasts and HBL melanoma cells, and in (C) composites contain keratinocytes, fibroblasts, HBL melanoma cells and $\alpha$-MSH/IBMX. Statistical comparison in (D) is made between $\mathrm{HBL}$ cell invasion in the absence (control) and presence of $\alpha$-MSH/IBMX. ${ }^{* * *} P<0.001$.

The HBL melanoma cell line has previously been demonstrated to express 1000-3000 MSH receptor-binding sites per cell (Ghanem et al, 1988), and A375 and C8161 melanoma cell lines have also been demonstrated to have MSH receptors (Baumann et al, 1997) and MSH binding sites (Sharma et al, 1996). In comparison, normal human cutaneous melanocytes are reported to express between 300 and 1000 binding sites per cell (Donatien et al, 1992; De Luca et al, 1993). In the present study, MC-1 receptors were identified on the cells by immunofluorescent microscopy, Western blotting and MSH binding sites using radiolabelled $\alpha-\mathrm{MSH}$. In addition, we also sequenced both alleles of the MC-1 receptor genomic DNA. Western blotting identified the presence of the MC-1 receptor at a molecular weight of $35 \mathrm{kDa}$, corresponding to the predicted molecular weight based on DNA sequencing data. As previously reported, binding studies confirmed that HBL melanoma cells had a relatively high receptor number. C8161 cells had a number approximating that found in normal skin melanocytes, while A375-SM cells had a relatively low number of receptors. However, all cells displayed similar receptor
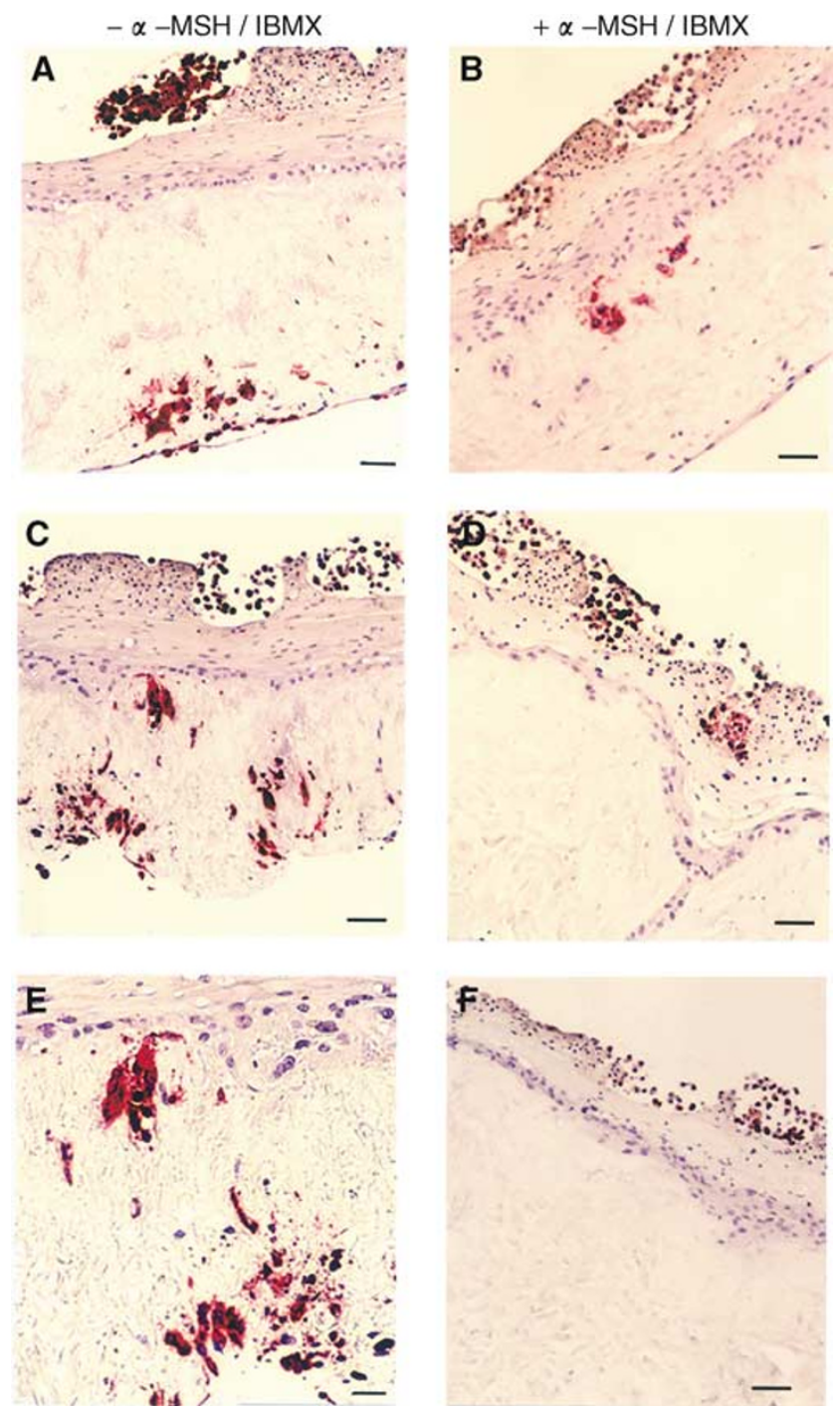

Figure 7 Histology of melanoma invasion through reconstructed skin composites containing keratinocytes, fibroblasts and $\mathrm{HBL}$ cells $\pm \alpha-\mathrm{MSH} /$ IBMX. Composites were cultured for I 4 days in the absence $(\mathbf{A}, \mathbf{C}$ and $\mathbf{E})$ and presence $(\mathbf{B}, \mathbf{D}$ and $\mathbf{F})$ of $\alpha-\mathrm{MSH}\left(|\times| 0^{-9} \mathrm{M}\right) / \mathrm{IBMX}(50 \mu \mathrm{M})$. Composites have been labelled for HMB45 (for detection of HBL cells). Bar for $(\mathbf{A})-(\mathbf{F})=40 \mu \mathrm{m}$; bar for $(\mathbf{E})=20 \mu \mathrm{m}$.

binding affinity for $\alpha$-MSH. (It was interesting to note that the HBL and A375-SM cell lines were also positive for the MC-2R, in contrast to the C8161 melanoma line.) Melanocortin-1 receptor DNA sequencing showed that the HBL line expressed wild-type MC-1R, whereas the A375-SM and C8161 lines were homozygous and heterozygous for Arg151Cys, respectively. This polymorphism is known to convey a loss of function on receptor coupling to cAMP (reviewed in Wikberg et al, 2000). The heterozygous expression of Arg151Cys would suggest a potential for signalling; however, partially functional responses in the A375-SM line (homozygous Arg151Cys) would suggest either that this polymorphism conveys some function (as opposed to total loss) or that a signal other than cAMP is conveyed from the receptor in a region outside of the Arg151Cys site.

A number of polymorphic studies of the MC receptor are related to incidence of melanoma (Box et al, 1997; Jiménez-Cervantes et al, 2001). However, not all studies are in agreement (Ichii-Jones et al, 1998). $\alpha$-Melanocyte-simulating hormone has been demonstrated to affect melanoma growth and attachment to ECM proteins in 

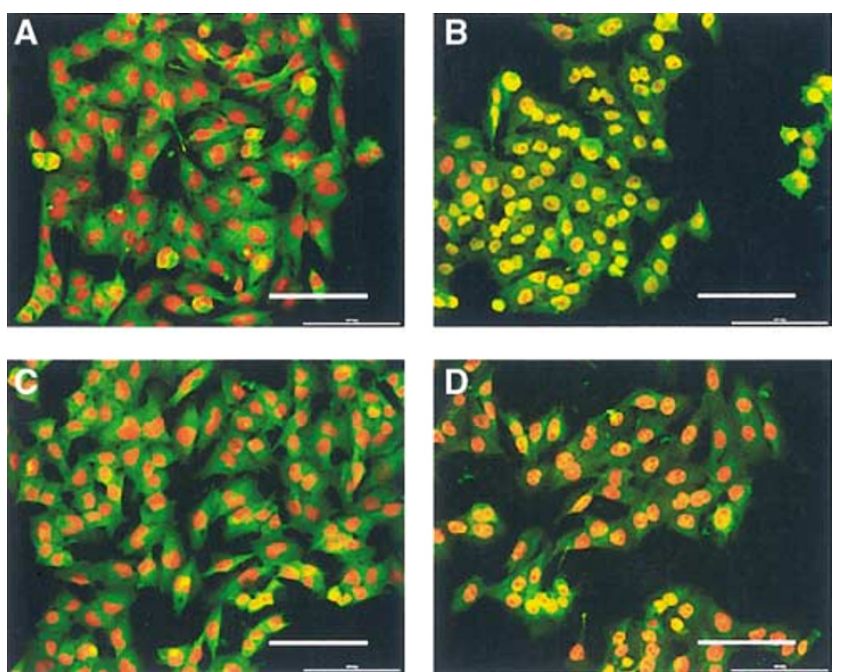

Figure 8 A375-SM melanoma cells immunolabelled for the p65 subunit of the NF- $\kappa \mathrm{B}$ complex. The p65 subunit (green fluorescence) was visualised using epifluorescent illumination (FITC filter, $\lambda_{\mathrm{ex}}=490 \mathrm{~nm}$, $\lambda_{\mathrm{em}}=523 \mathrm{~nm}$ ), while nuclei (red fluorescence) were visualised with a rhodamine filter $\left(\lambda_{\mathrm{ex}}=555 \mathrm{~nm}, \lambda_{\mathrm{em}}=580 \mathrm{~nm}\right)$. Cells were either left untreated $(\mathbf{A})$, stimulated with TNF- $\alpha\left(300 \mathrm{U} \mathrm{ml}^{-1}, 60 \mathrm{~min}\right)(\mathbf{B})$, treated with $\alpha-\mathrm{MSH}\left(10^{-9} \mathrm{M}\right)(\mathbf{C})$ alone, or pretreated with $\alpha-\mathrm{MSH}\left(10^{-9} \mathrm{M}\right.$, $15 \mathrm{~min}$ ) followed by stimulation with TNF- $\alpha\left(300 \mathrm{U} \mathrm{ml}^{-1}, 60 \mathrm{~min}\right)$ (D). Activation of NF- $\kappa \mathrm{B}$ is observed as translocation to the nucleus (TNF- $\alpha$ alone, B) and inhibition by $\alpha-M S H+T N F-\alpha$ as retention in the cytoplasm (D). $\operatorname{Bar}=100 \mu \mathrm{m}$.

cells with wild-type MC-1, but not in cells transfected with polymorphic variants (Robinson and Healy, 2002). The current study provides strong evidence to suggest that two out of three human cell lines that possessed MC-1R polymorphisms, which gave a loss of cAMP response to $\mathrm{MSH}$, resulted in cells that failed to respond to MSH with any reduction of invasion or protection against proinflammatory cytokine attack. Stable transfection of the C8161 cell line with the wild-type MC-1R and introduction of sensitivity to $\alpha$-MSH provides possibly the strongest evidence yet that this receptor is involved in melanoma invasiveness.

As previously stated, there is controversy concerning the role $\alpha$ MSH in the progression of melanoma. Most of the experimental studies have been carried out on murine melanoma cell lines, known to express between 3000 and $10000 \mathrm{MSH}$ binding sites per cell (Lambert and Lerner, 1983; Siegrist et al, 1989; Lunec et al, 1993), while human melanoma cells only express around 10003000 binding sites per cell (Ghanem et al, 1988). It is difficult to make firm conclusions concerning the role of $\alpha-\mathrm{MSH}$ in human melanoma progression from murine studies. The inhibitory effect of $\alpha$-MSH on the HBL cell line is similar to that reported previously (Murata et al, 1997) for highly invasive murine B16-BL6 melanoma cells. Melanoma invasion of the three cell lines was also inhibited (achieving significance for two out of three cell lines) by forskolin and/or IBMX (agents which elevate cAMP), supporting the idea that melanoma invasion is under the influence of adenylate cyclase/cAMP post-receptor signalling. This is consistent with earlier investigations showing a positive correlation between cAMP responsiveness of murine melanoma cell lines in vitro and the metastatic success of these lines in vivo (Sheppard et al, 1986; Hill et al, 1990).

The use of a reconstructed human skin model is particularly useful for studying melanoma cell invasion, as it provides a physiologically relevant dermal and epidermal structure (Eves et al, 2000). The melanoma cells are physically proximal to human keratinocytes and fibroblasts contained within an architecture that very closely approximates that of native skin tissue. The
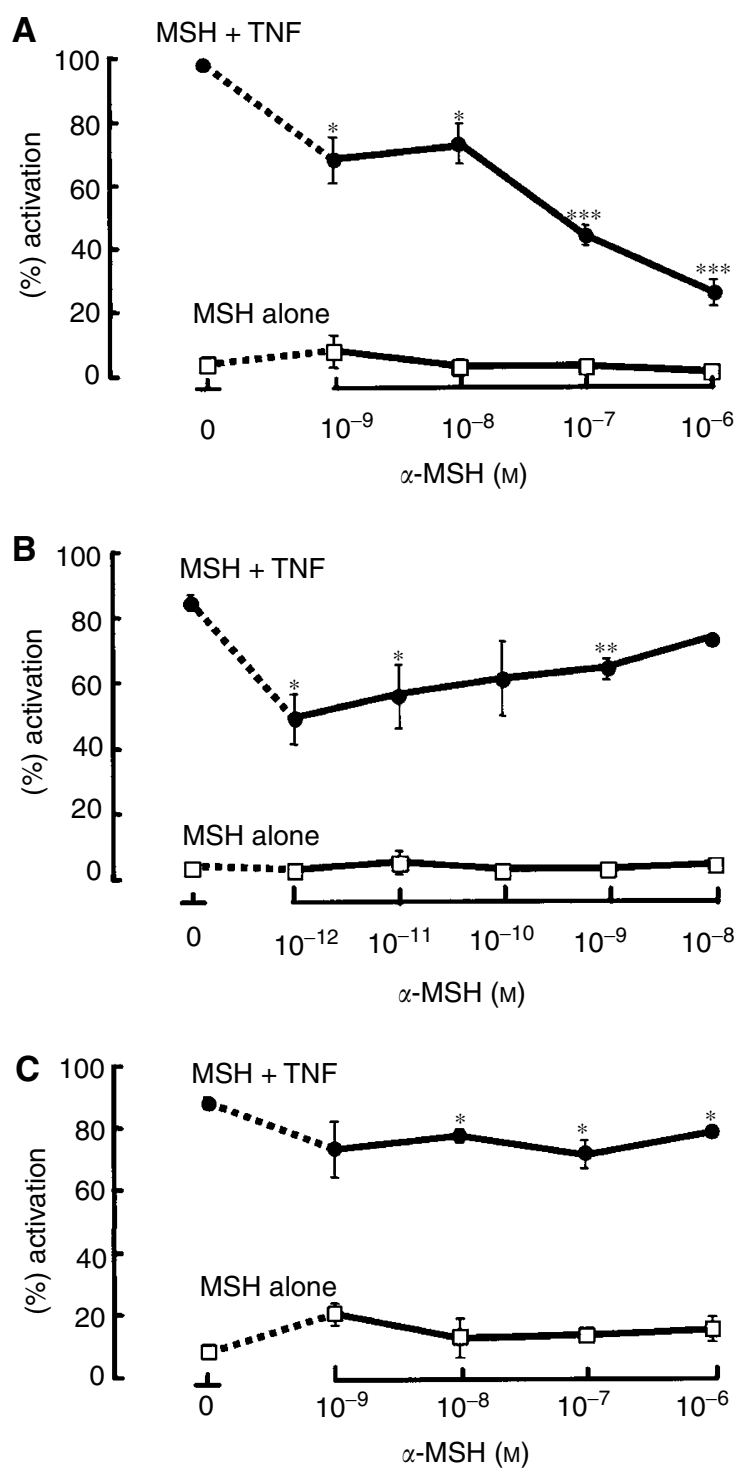

Figure 9 Effect of $\alpha-M S H$ on TNF- $\alpha$ stimulated NF- $\kappa$ B activity in $(\mathbf{A})$ HBL, (B) A375-SM and (C) C8I6I melanoma cells. Statistical comparison is made between cells treated with TNF- $\alpha$ alone and cells pretreated with $\alpha-\mathrm{MSH}$ followed by stimulation with TNF- $\alpha .{ }^{*} P<0.05,{ }^{* *} P<0.01$, ${ }^{* *} P<0.001$.

model also has a basement membrane structure, which is highly relevant to melanoma metastasis. Using this model we found that $\alpha$-MSH $\left(\right.$ at $\left.10^{-9} \mathrm{M}\right) / \mathrm{IBMX}\left(5 \times 10^{-5} \mathrm{M}\right)$ inhibited HBL melanoma cell invasion by $59 \%$.

$\alpha$-Melanocyte-simulating hormone can inhibit TNF- $\alpha$-stimulated NF- $\kappa \mathrm{B}$ activity in human melanocytes, melanoma cells and keratinocytes (Haycock et al, 1999, 2000; Moustafa et al, 2002). In all of these cells, $\alpha$-MSH inhibited the response to TNF- $\alpha$ by around $50 \%$. In the current study, TNF- $\alpha$ activated $\mathrm{NF} \kappa \mathrm{B} / \mathrm{p} 65$ in over $80 \%$ of all melanoma cells within $60 \mathrm{~min}$. The HBL melanoma line responded to $\alpha-\mathrm{MSH}$ with an inhibition of NF- $\kappa \mathrm{B}$. The A375SM melanoma line responded to low $\alpha-\mathrm{MSH}$ concentrations with an inhibition of NF- $\kappa$ B, whereas higher $\alpha$-MSH concentrations were ineffective. In contrast, C8161 cells were largely unresponsive to any $\alpha$-MSH concentrations.

The correlation observed between the anti-invasive response of the melanoma lines and the anti-inflammatory response to $\alpha$-MSH was very strong. We have shown previously that the anti- 
inflammatory response to $\alpha$-MSH is also mediated via cAMP, suggesting a strong correlation between anti-invasive and antiinflammatory responses. HBL melanoma cells responded to $\alpha$ MSH in a concentration-dependant manner with elevation in intracellular and extracellular cAMP (as did the murine B16 F10C1 melanoma line, used as a positive control). However, the A375-SM and C8161 lines had no detectable increases in cAMP. The lack of an $\alpha$-MSH response observed for the C8161 cells and a partial response for the A375-SM cells are consistent with the lack of a cAMP signal in these cells.

In contrast, all cell lines responded to $\alpha$-MSH with acute elevations in intracellular calcium. Dual signalling from the MC receptor is not a new concept. In 1984, $\alpha$-MSH-stimulated adenylate cyclase was reported to be regulated by calcium and calmodulin in a biphasic manner. Submicromolar concentrations of calcium were shown to be required for optimal $\alpha$-MSHstimulated cAMP production; slightly higher micromolar concentrations led to inhibition of adenylate cyclase (Mac Neil et al, 1984) and activation of calcium/calmodulin phosphodiesterase, resulting in cAMP breakdown in murine melanoma cells. In these same cells, $\alpha$-MSH was also demonstrated to activate protein kinase $\mathrm{C}$ (Buffey et al, 1992). Although $\alpha$-MSH may activate the phospholipase C signalling pathway (resulting in increased inositol phosphates, intracellular calcium and activation of protein kinase C) in addition to activating the adenylate cyclase cAMP signalling pathway, the overwhelming evidence from the literature (as reviewed in Eberle, 1988) points to the majority of the actions of $\alpha$-MSH being mediated by cAMP. The relevance of the dual signalling remains unclear although the calcium signal can modify the cAMP-mediated actions of $\alpha$-MSH on melanogenesis (Buffey et al, 1992). The simplest hypothesis to explain dual signalling is that most actions of the $\alpha$-MSH-induced phospholipase $\mathrm{C}$ signalling are explained by it suppressing the $\alpha$-MSH-induced cAMP signal (as proposed in Mac Neil et al, 1984). There is nothing in the current study to contradict this hypothesis as all of the functional biology of $\alpha$-MSH that we observed could be mimicked by elevating cAMP. The two cell lines that failed to generate a cAMP signal to $\alpha$-MSH did give a calcium signal, indicating that the receptors were adequately coupled to generate calcium but not cAMP.

The data obtained in this study highlight an interesting question regarding MC receptor expression and the functional activity of $\alpha$ MSH in melanoma cells. While immunofluorescent microscopy demonstrated that all three melanoma lines express MC-1 receptors, $\alpha$-MSH binding studies showed that only HBL cells have a high number of MSH receptors capable of generating a cAMP signal. Melanocortin-1 receptor polymorphisms have been associated with red hair and fair skin, and also with cutaneous melanoma in humans. Hence, it is of considerable interest that two of the lines investigated in this study contained homozygous and heterozygous polymorphisms, respectively. The Arg151Cys polymorphism, along with others (Arg160Trp and Arg294His) results in loss of receptor function, with association of an increased risk for melanoma (reviewed in Xia et al, 1995). The importance of receptor polymorphisms is further highlighted by the fact that when C8161 cells were stably transfected with the wild-type MC$1 \mathrm{R}$, the cells then responded with a significant inhibition of invasion in response to $\alpha-\mathrm{MSH}$.

\section{REFERENCES}

Baumann JB, Bagutti C, Siegrist W, Christen E, Zumsteg U, Eberle A (1997) MSH receptors and the response of human A375 melanoma cells to interleukin-1 $\beta$. J Recept Signal Transduc Res 17(1-3): 199-210

Bohm M, Metze D, Schulte U, Becher E, Luger TA, Brozoska T (1999) Detection of melanocortin-1 receptor antigenicity on human skin cells in culture and in situ. Exp Dermatol 8: 453-461
Melanoma cells that possess sufficient functional MC receptors may therefore respond to endogenous or exogenous $\alpha-\mathrm{MSH}$ with a reduction in their ability to invade through ECM proteins, and ability to resist proinflammatory cytokines. The former properties would tend to reduce melanoma invasion. Equally, it might be argued that resisting proinflammatory cytokine action is consistent with promoting melanoma invasion by assisting melanoma cells to escape immune surveillance. It is difficult to conclude how important the anti-invasive actions of $\alpha-\mathrm{MSH}$ in vitro are $v s$ the protective (and hence proinvasive) activity in preventing immune detection. We speculate that $\alpha$-MSH may retard melanoma escape from the primary tumour on the one hand (and initial metastasis), and on the other may promote melanoma invasion by reducing the response of cells to proinflammatory cytokines. Thus, a simple hypothesis to explain our present data would be that $\alpha$-MSH initially acts to reduce early tumour spread, but affords protection to those cells that do escape from a primary tumour site.

A major biological function of $\alpha$-MSH in the melanocyte, probably retained in the melanoma cell, may be the protection of cells from proinflammatory cytokines and oxidative stress. A common response of cells to such stress includes upregulation of adhesion molecules, some of which would normally bring cells to the attention of the immune system. Adhesion molecules such as integrins may also be upregulated and promote melanoma interaction with ECM proteins in terms of migration and invasion through the ECM. We have recently shown that while the proinflammatory cytokine TNF- $\alpha$ upregulates integrin $(\alpha 3, \alpha 4$, $\beta 1$ ) expression in HBL melanoma cells, treatment with $\alpha$-MSH results in a reduction in integrin expression ( $\mathrm{Zhu}$ et al, 2002). These results suggest that $\alpha$-MSH can effectively reduce cytokineinduced upregulation of adhesion molecules such as integrins that would tend to increase melanoma invasiveness through ECM proteins while also reducing expression of adhesion molecules that promote interaction between melanoma cells and the immune system (e.g. ICAM-1 as we previously demonstrated (Hedley et al, 1998b; Morandini et al, 1998)), thus enhancing melanoma escape of immune surveillance.

In conclusion, this study suggests that $\alpha$-MSH has the potential to retard metastatic spread but also to reduce the ability of the immune system to detect tumour cells, in some melanoma cells. Both responses to $\alpha$-MSH appear to be linked to the cAMP signalling pathway, but clearly the downstream signalling from the $\mathrm{MC}-1 \mathrm{R}$ is complex and far from resolved. As metastatic melanoma remains an extremely challenging cancer to treat, we suggest the role of $\alpha$-MSH in melanoma progression merits further investigation as it may hold clues to the metastatic success of the tumour and may offer new approaches to developing therapies to reduce metastatic spread or enhance the ability of these cells to be detected by the immune system.

\section{ACKNOWLEDGEMENTS}

We acknowledge the financial support of Yorkshire Cancer Research (YCR, UK), the Trustees of the Former United Sheffield Hospitals (Sheffield, UK) and the Northern General Hospital Medical and Cancer Research Trust (Sheffield, UK).
Box NF, Wyeth JR, O'Gorman LE, Martin MG, Sturm RA (1997) Characterisation of melanocyte stimulating hormone receptor variant alleles in twins with red hair. Human Mol Genet 269: 1897

Bregman MD, Meyskens Jr FL (1983) In vitro modulation of human and murine melanoma growth by prostanoid analogues. Prostaglandins 26: $449-456$ 
Buffey J, Thody AJ, Bleehen SS, Mac Neil S (1992) Melanocyte stimulating hormone stimulates protein kinase $\mathrm{C}$ activity in murine B16 melanoma. $J$ Endocrinol 133: $333-340$

Chakrabarty KH, Dawson RA, Harris P, Layton C, Babu M, Gould L, Phillips J, Leigh I, Green C, Freelander E, Mac Neil S (1999) Development of autologous human dermal-epidermal composites based on sterilised human allodermis for clinical use. Br J Dermatol 141: 811-823

Chakraborty AK, Funasaka Y, Slominski A, Ermak G, Hwang J, Pawelek JM, Ichihashi M (1996) Production and release of proopiomelanocortin (POMC) derived peptides by human melanocytes and keratinocytes in culture: regulation by ultraviolet B. Biochim Biophys Acta 1313: 130-138

De Luca M, Siegrist W, Bondanza S, Mathor M, Cancedda R, Eberle AN (1993) Melanocyte stimulating hormone $(\alpha \mathrm{MSH})$ stimulates normal human melanocyte growth by binding to high-affinity receptors. J Cell Sci 105: $1079-1084$

Dewhurst LO, Gee JW, Rennie IG, MacNeil S (1997) Tamoxifen, 17 $\beta$ oestradiol and the calmodulin antagonist J8 inhibit human melanoma cell invasion through fibronectin. Br J Cancer 75(6): 860-868

Donatien PD, Hunt G, Pieron C, Lunec J, Taieb A, Thody AJ (1992) The expression of functional MSH receptors on cultured human melanocytes. Arch Dermatol Res 284: 424-426

Eberle AN (1988), The Melanotropins: Chemistry, Physiology and Mechanisms of Action. pp 1-439. Basel: Karger

Eves P, Layton C, Hedley S, Dawson RA, Wagner M, Morandini R, Ghanem G, Mac Neil S (2000) Characterisation of an in vitro model of human melanoma invasion based on reconstructed human skin. $\mathrm{Br} J$ Dermatol 142: 210-222

Friedmann PS, Wren F, Buffey J, Mac Neil S (1990) $\alpha$-MSH causes a small rise in cAMP but has no effect on basal or ultraviolet-stimulated melanogenesis in human melanocytes. Br J Dermatol 123: 145-151

Ghanem G, Verstegen J, De Rijcke S, Hanson P, Van Onderbergen A, Libert A, Del Marmol V, Arnould R, Vercammen-Grandjean A, Lejeune F (1989a) Studies on factors influencing human plasma alpha-MSH. Anticancer Res 9(6): 1691 - 1696

Ghanem G, Verstegen J, Libert A, Arnould R, Lejeune F (1989b) Alphamelanocyte stimulating hormone immunoreactivity in human melanoma metastases extracts. Pigment Cell Res 2(6): 519-523

Ghanem GE, Comunale G, Libert A, Vercammen-Grandjean A, Lejeune FJ (1988) Evidence for alpha-melanocyte stimulating hormone $(\alpha-\mathrm{MSH})$ receptors on human malignant melanoma cells. Int J Cancer 41: 248-255

Ghosh S, May MJ, Kopp EB (1998) NF- $\kappa$ B and rel proteins: evolutionarily conserved mediators of immune responses. Ann Rev Immunol 16: $225-260$

Giard DJ, Aaronson SA, Todaro GJ, Arnstein P, Kersey JH, Dosik H, Parks WP (1973) In vitro cultivation of human tumours: establishment of cell lines derived from a series of solid tumours. J Natl Cancer Inst 51: $1417-1423$

Haycock JW, Rowe SJ, Cartledge S, Wyatt A, Ghanem G, Morandini R, Rennie IG, Mac Neil S (2000) Melanocyte-stimulating hormone reduces impact of proinflammatory cytokine and peroxide-generated oxidative stress on keratinocytes and melanoma cell lines. J Biol Chem 275: 15629 15636

Haycock JW, Wagner M, Morandini R, Ghanem G, Rennie IG, Mac Neil S (1999) Melanocyte stimulating hormone inhibits NF- $\kappa$ B activation in human melanocytes and melanoma cells. J Invest Dermatol 113: 560 - 566

Hedley SJ, Gawkrodger DJ, Weetman AP, Mac Neil S (1998a) MSH and melanogenesis in normal human adult melanocytes. Pigment Cell Res 11: $45-56$

Hedley SJ, Gawkrodger DJ, Weetman AP, Morandini R, Boeynaems J-M, Ghanem G, Mac Neil (1998b) Melanocyte stimulating hormone inhibits tumour necrosis factor- $\alpha$ stimulated intercellular adhesion molecule- 1 expression in normal cutaneous human melanocytes and in melanoma cell lines. Br J Dermatol 138: 536-543

Hedley SJ, Layton C, Heaton M, Chakrabarty KH, Dawson RA, Gawkrodger DJ, Mac Neil S (2002) Fibroblasts play a regulatory role in the control of pigmentation in reconstructed human skin from skin types I and II. Pigment Cell Res 15: $49-56$

Hedley SJ, Murray A, Sisley K, Ghanem G, Morandini R, Gawkrodger DJ, Mac Neil S (2000) Melanocyte stimulating hormone can reduce T-cell interaction with melanoma cells in vitro. Melanoma Res 10(4): $323-330$

Hill SE, Rees RC, Mac Neil S (1990) A positive association between agonistinduced cyclic AMP production in vitro and metastatic potential in murine B16 melanoma and hamster fibrosarcoma. Clin Exp Metast 8(5): $461-474$
Hunt G, Todd, Cresswell JE, Thody AJ (1994) Melanocyte stimulating hormone and its analogue $\mathrm{Nle}^{4} \mathrm{DPhe}^{7} \alpha-\mathrm{MSH}$ affect morphology, tyrosinase activity and melanogenesis in cultured human melanocytes. J Cell Sci 107: 205-211

Ichii-Jones F, Lear JT, Heagerty AHM, Smith AG, Hutchinson PE, Osborne J, Bowers B, Jones PW, Davies E, Ollier WE, Thomson W, Yengi L, Bath J, Fryer AA, Strange RC (1998) Susceptibility to melanoma: influence of skin type and polymorphism in the melanocyte stimulating hormone receptor gene. J Invest Dermatol 111: 218-221

Jiménez-Cervantes C, Germer S, González P, Sánchez J, Sánchez CO, García-Borrón JC (2001) Thr40 and Met122 are new partial loss-offunction natural mutations of the human melanocortin 1 receptor. FEBS Lett 508: $44-48$

Kameyama K, Vieira WD, Tsukamoto K, Law LW, Hearing V (1990) Differentiation and the tumourigenic and metastatic phenotype of murine melanoma cells. Int J Cancer 45(6): 1151-1158

Kippenberger S, Bernd A, Loitsch S, Ramirez-Bosca A, Bereiter-Hahn J, Holzmann H (1995) MSH is expressed in cultured human melanocytes and keratinocytes. Eur J Dermatol 5: 395-397

Kozlowski JM, Hart IR, Fidler IJ, Hanna N (1984) A human melanoma line heterogeneous with respect to metastatic capacity in athymic nude mice. J Natl Cancer Inst 72(4): $913-917$

Lambert DT, Lerner AB (1983) Optimisation of a melanotropin-receptor binding assay by reversed-phase high-performance liquid chromatography. J Chromatogr 266: 567-576

Lerner AB, McGuire JS (1961) Effect of $\alpha$ - and $\beta$-melanocyte stimulating hormones on skin colour of man. Nature 21: 176-179

Lipton JM, Catania A (1997) Anti-inflammatory actions of the neuroimmunomodulator $\alpha$-MSH. Immunol Today 18(3): $140-145$

Liu PY, Johansson O (1995) Immunohistochemical evidence of alpha-, beta- and gamma-3 melanocyte stimulating hormone expression in cutaneous malignant melanoma of nodular type. J Dermatol Sci 10(3): $203-212$

Luger TA, Schwarz T, Kalden H, Scholzen T, Schwarz A, Brzoska T (1999), Role of epidermal cell-derived $\alpha-\mathrm{MSH}$ in ultraviolet light mediated local immunosuppression. In Cutaneous Neuroimmunomodulation; The Proopiomelanocortin System . Luger TA, Paus R, Lipton JM, Slominski AT (eds) pp 209-216. New York: The New York Academy of Sciences

Lunec J, Pieron C, Bal W, Mac Neil S, Thody AJ (1993) MSH receptors and function in amelanotic B16 melanoma cells. Melanoma Res 3: 99-106

Mac Neil S, Walker SW, Senior HJ, Pollock A, Brown BL, Bleehen SS, Munro DS, Tomlinson S (1984) Calmodulin activation of adenylate cyclase in the mouse B16 melanoma. Biochem J 224: 453-460

Metcalfe RA, Findlay C, Robertson WR, Weetman AP, MacNeil S (1998) Differential effect of thyroid-stimulating hormone (TSH) on intracellular free calcium and cAMP in cells transfected with the human TSH receptor. J Endocrinol 157: $415-424$

Morandini R, Boeynaems JM, Hedley SJ, Mac Neil S, Ghanem G (1998) Modulation of ICAM-1 expression by $\alpha$-MSH in human melanoma cells and melanocytes. J Cell Physiol 175: 276-282

Mountjoy KG, Robbins LS, Mortrud MT, Cone RD (1992) The cloning of a family of genes that encode the melanocortin receptors. Science 257(5074): $1248-1251$

Moustafa M, Szabo M, Ghanem G, Morandini R, Kemp EH, Mac Neil S, Haycock JW (2002) Inhibition of TNF- $\alpha$ stimulated NF- $\kappa \mathrm{B} / \mathrm{p} 65$ in human keratinocytes by $\alpha$-melanocyte stimulating hormone and adrenocorticotrpic hormone peptides. J Invest Dermatol 119(6): 1244-1253

Murata J, Ayukawa K, Ogasawara M, Fujii H, Saiki I (1997) Melanocyte stimulating hormone blocks invasion of reconstituted basement membrane (matrigel) by murine B16 melanoma cells. Invas Metast 17: $82-93$

Richardson B, Price A, Wagner M, Williams V, Lorigan P, Browne S, Miller JG, Mac Neil S (1999) Investigation of female survival benefit in metastatic melanoma. Br J Cancer 80(12): 2025-2033

Robinson SJ, Healy E (2002) Human melanocortin 1 receptor (MC1R) gene variants alter melanoma cell growth and adhesion to extracellular matrix. Oncogene 21(52): $8037-8046$

Schauer E, Trautinger F, Kock A, Schwarz A, Bhardwaj R, Simon M, Ansel JC, Schwarz T, Luger TA (1994) Proopiomelanocortin-derived peptides are synthesised and released by human kerationcytes. J Clin Invest 93(5): 2258-2262

Schiöth HB, Phillips SR, Rudzish R, Birch-Machin MA, Wikberg JES, Rees JL (1999) Loss of function mutations of the human melanocortin 1 receptor are common and are associated with red hair. Biochem Biophys Res Commun 260: 488 -491 
Sharma SD, Jiang J, Hadley ME, Bentley DL, Hruby VJ (1996) Melanotropic peptide-conjugated beads for microscopic visualisation and characterisation of melanoma melanotropin receptors. Proc Natl Acad Sci USA 93: $13715-13720$

Sheppard JR, Koestler TP, Corwin S, Buscarino C, Doll J, Lester B, Greig RG, Poste G (1984) Experimental metastasis correlates with cyclic AMP accumulation in B16 melanoma clones. Nature 308: $544-547$

Sheppard JR, Lester B, Doll J, Buscarino C, Gonzales E, Corwin S, Greig R, Poste G (1986) Biochemical regulation of adenylate cyclase in murine melanoma clones with different metastatic properties. Int J Cancer 37: $713-722$

Siegrist W, Solca F, Stutz S, Giuffre L, Carrel S, Girard J, Eberle AN (1989) Characterisation of receptors for alpha-melanocyte stimulating hormone on human melanoma cells. Cancer Res 49: 6352-6358
Valverde P, Healy E, Jackson I, Rees JL, Thody AJ (1995) Variants of the melanocyte-stimulating hormone receptor gene are associated with red hair and fair skin in humans. Nat Genet 11: 328-330

Wikberg JE, Muceniece R, Mandrika I, Prusis P, Lindblom J, Post C, Skottner A (2000) New aspects on the melanocortins and their receptors. Pharm Res 42: $393-420$

Xia Y, Skoog V, Muceniece R, Chhajlani V, Wikberg JE (1995) Polyclonal antibodies against human melanocortin $\mathrm{MCl}$ receptor: preliminary immunohistochemical localisation of melanocortin MC1 receptor to malignant melanoma cells. Eur J Pharmacol 288(3): 277-283

Zhu N, Eves PC, Katerinaki E, Szabo M, Morandini R, Ghanem G, Lorigan P, Mac Neil S, Haycock JW (2002) Melanoma cell attachment, invasion, and integrin expression is upregulated by tumour necrosis factor alpha and suppressed by alpha melanocyte stimulating hormone. J Invest Dermatol 119(5): 1165-1171 